\title{
3
}

PNL-3640

UC-11

\section{The Incipient Toxicity of \\ Lithium to Freshwater \\ Organisms Representing a Salmonid Habitat}
R. Emery
D. C. Klopfer
J. R. Skalski

July 1981

Prepared for the U.S. Department of Energy under Contract DE-AC06-76RLO 1830

Pacific Northwest Laboratory Operated for the U.S. Department of Energy by Battelle Memorial Institute

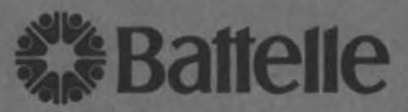


NOTICE

This report was prepared as an account of work sponsored by the United States Government. Neither the United States nor the Department of Energy, nor any of their employees, nor any of their contractors, subcontractors, or their employees. makes any warranty, express or implied, or assumes any legal liability or responsibility for the accuracy, completeness or usefulness of any information, apparatus, product or process disclosed, or represents that its use would not infringe privately owned rights.

The views, opinions and conclusions contained in this report are those of the contractor and do not necessarily represent those of the United States Government or the United States Department of Energy.

\author{
PACIFIC NORTHWEST LABORATORY \\ operated by \\ BATTELLE \\ for the \\ UNITED STATES DEPARTMENT OF ENERGY \\ Under Contract DE-AC06-76RLO 1830
}
Printed in the United States of America
Available from
National Technical Information Service
United States Department of Commerce
5285 Port Royal Road
Springfield, Virginia 22151

Price: Printed Copy 5 $\therefore$ Microfiche $\$ 3.00$

NTIS

-Pages Selling Price

$\begin{array}{ll}001-025 & \$ 4.00 \\ 026-050 & \$ 4.50 \\ 051-075 & \$ 5.25 \\ 076-100 & \$ 6.00 \\ 101-125 & \$ 6.50 \\ 126-150 & \$ 7.25 \\ 151-175 & \$ 8.00 \\ 176-200 & \$ 9.00 \\ 201-225 & \$ 9.25 \\ 226-250 & \$ 9.50 \\ 251-275 & \$ 10.75 \\ 276-300 & \$ 11.00\end{array}$


PNL -3640

UC -11

\section{8}

THE INCIPIENT TOXICITY OF LITHIUM TO FRESHWATER ORGANISMS REPRESENTING A SALMONID HABITAT
R. Emery
D. C. Klopfer
J. R. Skalski

July 1981

Prepared for the U.S. Department of Energy under Contract DE-AC06-76RL0 1830

Pacific Northwest Laboratory

Richland, Washington 99352 
,

.

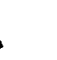

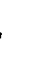


Eventual development of fusion power reactors could increase the mining, use and disposal of lithium five-fold by the year 2000. This study has investigated potential effects from unusual amounts of lithium in aquatic environments. Freshwater organisms representing a Pacific Northwest salmonid habitat were exposed to elevated concentrations of lithium. Nine parameters were used to determine the incipient toxicity of lithium to rainbow trout (Salmo gairdneri), insect larvae (Chironomus sp.) and Columbia River periphyton. All three groups of biota were incipiently sensitive to lithium at concentrations ranging between 0.1 and $1 \mathrm{mg} / \mathrm{L}$. These results correspond with the incipient toxicity of beryllium, a chemically similar component of fusion reactor cores. A maximum lithium concentration of $0.01 \mathrm{mg} / \mathrm{L}$ occurs naturally in most freshwater environments (beryllium is rarer). Therefore, a concentration range of 0.01 to $0.1 \mathrm{mg} / \mathrm{L}$ may be regarded as "approaching toxic concentrations" when assessing the hazards of lithium in freshwaters. 


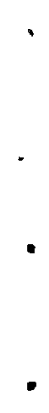




\section{CONTENTS}

\begin{tabular}{|c|c|c|c|c|c|c|c|c|c|c|c|c|c|c|}
\hline ABSTRACT & - & - & & - & - & & • & • & & - & - & • & $\cdot$ & ii \\
\hline \multicolumn{2}{|c|}{ INTRODUCTION } & - & • & - & - & & - & - & & - & - & - & • & 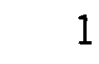 \\
\hline \multicolumn{4}{|c|}{ EXPER IMENTAL APPROACH } & - & - & & - & - & & - & - & - & $\bullet$ & 3 \\
\hline RESULTS & - & . & & - & • & & - & . & & - & - & • & . & 4 \\
\hline \multicolumn{2}{|l|}{ DISCUSSION } & . & • & - & • & & - & - & & - & - & • & $\cdot$ & 15 \\
\hline \multicolumn{4}{|c|}{ SUMMARY AND CONCLUSION } & - & - & & - & . & & - & - & - & • & 20 \\
\hline \multicolumn{3}{|c|}{ ACKNOWLEDGEMENT } & • & - & • & & - & - & & - & - & - & 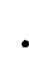 & 21 \\
\hline \multicolumn{2}{|l|}{ REFERENCES } & • & • & - & • & & - & - & & - & • & • & • & 22 \\
\hline APPENDIX A & & PER IMEN & VTAL & ME & HOD & & - & - & & - & - & • & • & A.1 1 \\
\hline \multirow[t]{5}{*}{1.0} & RAII & BOW TRO & DUT E & EXP & RIM & IENTS & & - & & - & - & • & 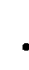 & A. 1 \\
\hline & 1.1 & EARLY & DEVE & ELO & MEN & ITAL & STA & AES & & - & - & - & $\bullet$ & A. 1 \\
\hline & & 1.1 .1 & Che & emi & al & Para & amet & ers & & . & . & . & 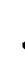 & A. 1 \\
\hline & & 1.1 .2 & $\mathrm{Bic}$ & 010 & jica & $1 \mathrm{~Pa}$ & arame & ter & & . & . & - & 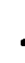 & A. 6 \\
\hline & 1.2 & JUVENI & ILES & - & - & & - & • & & - & - & - & 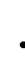 & A. 8 \\
\hline \multirow[t]{3}{*}{2.0} & EXPE & RIMENTS & WIT & & OLU & MBIA & A RI & IER & $\mathrm{BIO}$ & OTA & - & - & 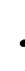 & A. 13 \\
\hline & 2.1 & THE EX & $\langle P E R$ & IME & ITAL & SYS & STEM & - & & . & - & - & 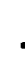 & A. 13 \\
\hline & 2.2 & MEASUR & REMEI & NTS & OF & BIOL & LOGI & CAL & PAR & RAME & ERS & • & & A. 1 \\
\hline
\end{tabular}




\section{FIGURES}

1 Effects of elevated $\mathrm{Li}^{+}$concentrations on trout egg integrity .

2 Effects of elevated $\mathrm{Li}^{+}$concentrations on trout egg fertilization

3 Effects of elevated $\mathrm{Li}^{+}$concentrations on the success of trout egg embryogensis

4 Effects of elevated $\mathrm{Li}^{+}$concentrations on hatching success of trout eggs

5 Survival of trout sac fry undergoing embryogenesis in elevated $\mathrm{Li}^{+}$ concentrations

6 Survival of juvenile trout in elevated $\mathrm{Li}^{+}$concentrations .

7 Effects of elevated $\mathrm{Li}^{+}$concentrations or relative accumulations of periphyton biomass

8 Effect of elevated $\mathrm{Li}^{+}$concentrations on relative photosynthetic rates of periphyton. Circles display test numbers .

9 Effects of elevated $\mathrm{Li}^{+}$concentrations on the relative habitation of chironomid larvae

10 An array of all LRCT data from Figures 1 through 9 and Table 1 .

A1 Recirculating exposure chambers for testing trout egg development in elevated $\mathrm{Li}^{+}$concentrations $\quad . \quad . \quad . \quad . \quad . \quad . \quad$.

A2 The serial dilution system used to deliver elevated $\mathrm{Li}^{+}$ concentrations to Columbia River biota . . . . . . . A.14

A3 Experimental array and detail of exposure containers used to test Columbia River biota in elevated $\mathrm{Li}^{+}$concentrations 


\section{TABLES}

1 The LRCT expressions defining incipiently toxic concentrations of $\mathrm{Li}^{+}$for all tests and experimental parameters . . . .

A1 Experimental conditions and results of the first test where early stages of trout development were exposed to elevated concentrations

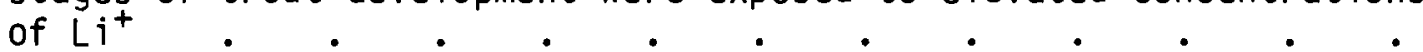

A2 Experimental conditions and results of the second test where early stages of trout development were exposed to elevated $\mathrm{Li}^{+}$ concentrations

A3 Experimental conditions and results of the third test where early stages of trout development were exposed to elevated $\mathrm{Li}^{+}$ concentrations.

A4 Statistical answers to two questions regarding the toxicity of LiF and $\mathrm{Li}_{2} \mathrm{CO}_{3}$.

A5 Experimental conditions and results of the first test where juvenile trout were exposed to elevated $\mathrm{Li}^{+}$concentrations

A6 Experimental conditions and results of the second test where juvenile trout were exposed to elevated $\mathrm{Li}^{+}$concentrations

A7 Experimental conditions and results of the third test where juvenile trout were exposed to elevated $\mathrm{L}^{+}$concentrations

A8 Experimental conditions and results of the first test where periphyton and insect larvae were exposed to elevated $\mathrm{Li}^{+}$ concentrations.

A9 Experimental conditions and results of the second test where periphyton and insect larvae were exposed to elevated $\mathrm{Li}^{+}$ concentrations

A10 Experimental conditions and results of the third test where periphyton and insect larvae were exposed to elevated $\mathrm{Li}^{+}$ concentrations.

A11 Experimental conditions and results of the fourth test where periphyton and insect larvae were exposed to elevated $\mathrm{Li}^{+}$ concentrations . 


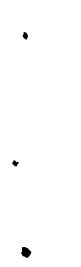


THE INCIPIENT TOXICITY OF LITHIUM TO

FRESHWATER ORGANISMS REPRESENTING A SALMONID HABITAT

\section{INTRODUCTION}

During the 1960 's, scientists became increasingly aware that the element lithium was unusually toxic to plant life. In 1968, the U.S. Federal Water Pollution Control Administration recommended that lithium ion $\left(\mathrm{Li}^{+}\right)$concentrations in irrigation water be 1 imited to $5 \mathrm{ppm}$ (U.S. FWPCA 1968). However, no standards have been established for $\mathrm{Li}^{+}$in natural aquatic environments by the Environmental Protection Agency (U.S. EPA 1976).

Natural concentrations of $\mathrm{Li}^{+}$in freshwater environments vary with different salinity regimes. Data for major rivers in North America show a median $\mathrm{Li}^{+}$concentration of $0.0011 \mathrm{mg} / \mathrm{L}$ (Durum and Haffty 1961). Maximum concentrations among these data approached $0.01 \mathrm{ppm}$. Minimum $\mathrm{Li}^{+}$concentrations were below detectability. These observations are consistent with those of water supply specialists who investigated over 100 freshwater systems in the U.S. (Durfor and Becker 1964).

Other investigators reported somewhat lower concentrations of $\mathrm{Li}^{+}$in freshwater environments that they investigated. The highest concentrations of $\mathrm{Li}^{+}$they reported in some North American ponds and streams approached $0.003 \mathrm{mg} / \mathrm{L}$ (Cowgill 1976, Vine 1976). However, in aquatic systems with higher salinity, often identified as brackish waters with total salinity exceeding $250 \mathrm{mg} / \mathrm{L}, \mathrm{Li}^{+}$ concentrations approached $0.1 \mathrm{mg} / \mathrm{L}$ (Vine 1976). Of all inland waters considered collectively, highest $\mathrm{Li}^{+}$concentrations are in salt lakes and hot springs. In these environments where total salinity exceeded $500 \mathrm{ppm}$, maximum $\mathrm{Li}^{+}$concentrations approach $10 \mathrm{mg} / \mathrm{L}$.

Based on all of this information, it is reasonable to conclude that the "normal spectrum of freshwater environments" (for which this assessment seeks to protect) can tolerate $\mathrm{Li}^{+}$concentrations up to $0.01 \mathrm{mg} / \mathrm{L}$.

Effects of $\mathrm{Li}^{+}$on aquatic life now becomes a more-important issue because the development and use of fusion reactors will increase the demand for lithium 
by several-fold over the next few decades. Fusion rectors will use lithium to generate deuterium and, possibly, as a liquid-metal coolant. The present total demand for lithium by the U.S. is $2.7 \times 10^{6} \mathrm{~kg} / \mathrm{yr}$. This will likely increase to at least $1.2 \times 10^{7} \mathrm{~kg} / \mathrm{yr}$ by the turn of the century (Vine 1976).

There is $6.9 \times 10^{8} \mathrm{~kg}$ of lithium presently available in rock ores, and $4.0 \times 10^{9} \mathrm{~kg}$ in fines associated with salt lakes. However, by the year 2030, these resources may be sufficiently depleted to necessitate extracting lithium from seawater where there is $2.5 \times 10^{14} \mathrm{~kg}$ available. For at least the next 50 years, the major source of lithium for fusion technology will be brines associated with inland aquatic environments (Vine 1976).

Compounds of lithium that would most likely enter freshwater environments from mining, refining, fabrication, and use are the carbonates, fluorides, oxides, hydroxides, and sulfates. Fluorides and carbonates of lithium appear to be the most probable environmental contaminants.

Literature on the subject of $\mathrm{Li}^{+}$toxicity to aquatic life is sparse. What has been reported is often difficult to interpret. Difficulties lie in answering the fundamental assessment question that pertains to the incipient toxicity of $\mathrm{Li}^{+}$. Of greatest importance to the initial stages of an environmental hazards assessment is to ascertain a "threshold" or incipient level of toxicity. Above such a concentration biological effects are known to occur, and below it no effects have been recorded. This information is essential for assessing risks and hazards of any chemical substance.

The purpose of this investigation is to determine what biological damage might occur if $\mathrm{Li}^{+}$concentrations (as in fluoride and carbonate compounds) exceeded tolerable levels in freshwater environments. The scope of this investigation is limited to habitats of salmonid fishes. Our objective is to identify the lowest concentrations of $\mathrm{Li}^{+}$that produces measurable effects in our experimental organisms. Biological parameters for which effects were measured fall into two categories:

1. Rainbow trout (Salmo gairdneri) life cycle:

a. Egg integrity--The integrity of the eggs' protective membranes in elevated $\mathrm{Li}^{+}$concentrations. 
b. Fertilization success-- The ability of eggs having integrity to become fertilized in elevated $\mathrm{Li}^{+}$concentrations.

c. Completion of embryogenesis--The ability of the fertilized eggs to complete embryogenes is in elevated $\mathrm{Li}^{+}$concentrations.

d. Hatchability--The ability of surviving trout embryos to hatch in elevated $\mathrm{Li}^{+}$concentrations.

e. Fry survival--The ability of sac fry to complete their "buttoning-up" process after having undergone embryogenesis in elevated $\mathrm{Li}^{+}$ concentrations.

f. Juvenile survival--The ability of juvenile trout to survive elevated $\mathrm{Li}^{+}$concentrations.

2. Colonization and habitation of Columbia River biota:

a. Biomass--The ability of periphyton biomass to become established in elevated $\mathrm{Li}^{+}$concentrations.

b. Photosynthesis rate--The ability of colonized periphyton to perform photosynthesis in elevated $\mathrm{Li}^{+}$concentrations.

c. Insect habitation--The extent to which insect larvae will remain in sediments exposed to elevated $\mathrm{Li}^{+}$concentrations.

\section{EXPERIMENTAL APPROACH}

Floride and carbonate compounds of $\mathrm{Li}^{+}$were used in our toxicity bioassays. The six rainbow trout parameters were examined in an experimental sequence of three test runs. Measurements of the river-biota parameters involved four test runs. Experimental details of these tests are described in Appendix $A$.

In all tests, the objective was to identify the lowest concentration of $\mathrm{Li}^{+}$that produced measurable effects in each parameter. These $\mathrm{Li}^{+}$concentrations are defined statistically as LRCT's (Lowest Rejected Concentration Tested, Skalski 1981) using chi-square tests for equal proportions in independent 
samples (Tables $\mathrm{A} 1-\mathrm{A} 3, \mathrm{A5}-\mathrm{A} 7$ ). Analyses of the effects of $\mathrm{Li}^{+}$on trout embryos (Tables A1-A3) took into account the successful completion of all previous stages of embryonic development.

\section{RESULTS}

Our primary mission was to determine LRCTs of $\mathrm{Li}^{+}$using rainbow trout, Columbia River periphyton and chironomid larvae as test organisms. These concentrations defined incipient levels of $\mathrm{Li}^{+}$toxicity and provide fundamental reference points for hazards assessment and regulation. Here are the results of our search for LRCTs in nine biological parameters.

Trout Egg Integrity:

LRCTs were relatively high in the first test $\left(76\right.$ and $108 \mathrm{mg} \mathrm{Li}{ }^{+} / \mathrm{L}$, Fig. 1). The second and third tests produced LRCTs ranging from 4.3 to $8.8 \mathrm{mg}$ $\mathrm{Li}^{+} / \mathrm{L}$. For this parameter the incipient level of toxicity for $\mathrm{Li}^{+}$seems to approach $1 \mathrm{mg} / \mathrm{L}$. Above this concentration the integuments of trout eggs began to deteriorate.

Trout Egg Fertilization:

The process of fertilization was surprisingly tolerant to elevated $\mathrm{Li}^{+}$ concentrations (Fig. 2). Our test results suggest that $\mathrm{Li}^{+}$concentrations of $<70 \mathrm{mg} / \mathrm{L}$ may actually enhance fertilization--perhaps as a membrane conditioner or as a biocidal agent against hostile microbes. These results appear too consistently to dismiss as pure anomaly. The only LRCTs that could be identified were in tests 1 and 3 in $\mathrm{Li}_{2} \mathrm{CO}_{3}$ solutions. Respectively, these are 70 and $108 \mathrm{mg} \mathrm{Li} / \mathrm{L}$, and too high to be of real concern for most assessment situations.

Trout Embryogensis:

Embryogensis displayed a broad range of tolerance to $\mathrm{Li}^{+}(4.6$ to $108 \mathrm{mg} / \mathrm{L}$, Fig. 3). Tests 2 and 3 demonstrated that LRCTs could occur below $10 \mathrm{mg} \mathrm{Li} / \mathrm{L}^{+}$ Therefore, $\mathrm{Li}^{+}$may be regarded as incipiently toxic to this parameter at concentrations in excess of $1 \mathrm{mg} / \mathrm{L}$. 

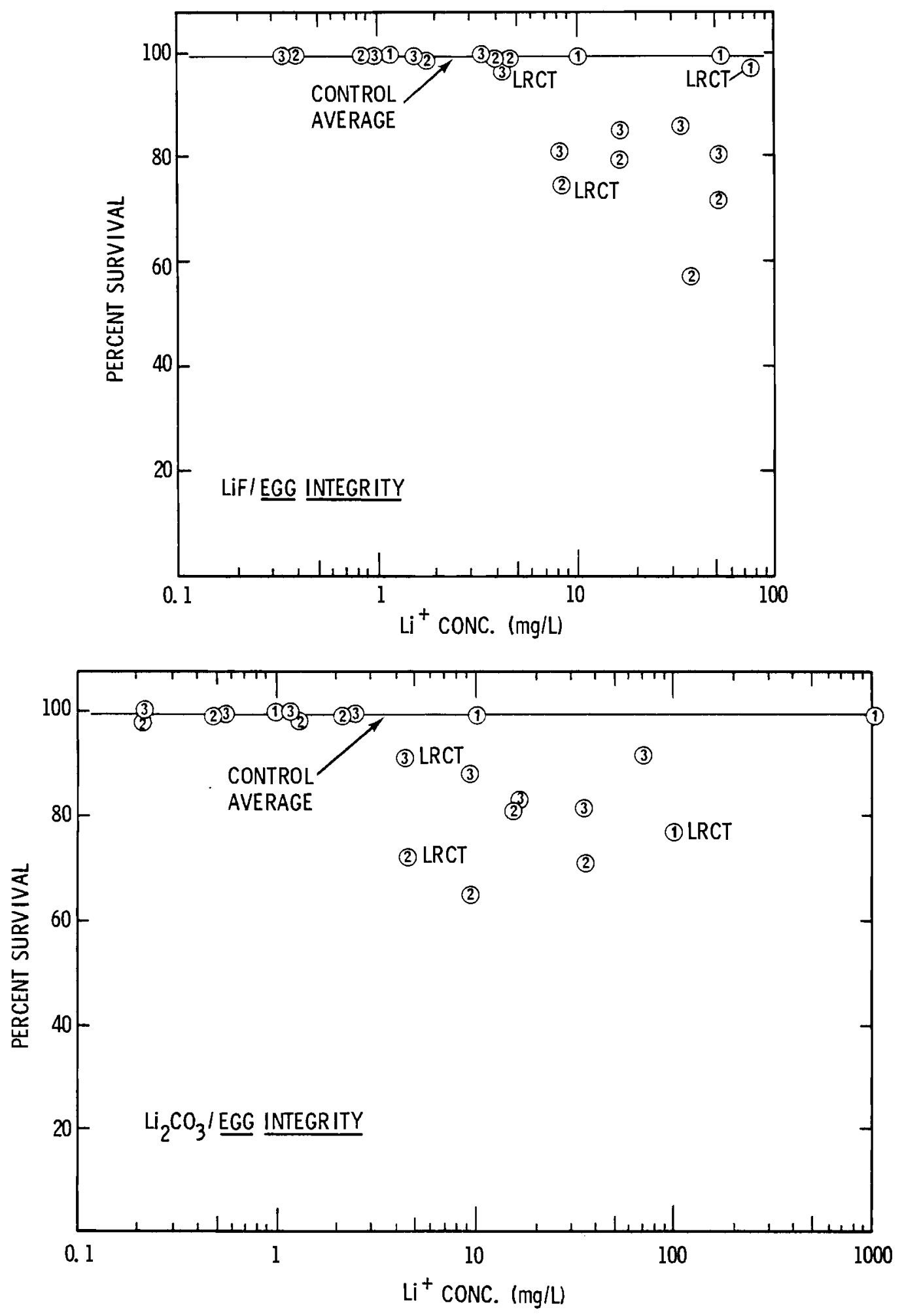

FIGURE 1. Effects of elevated $\mathrm{Li}^{+}$concentrations on trout egg integrity. Results (circles) display test numbers respectively. 

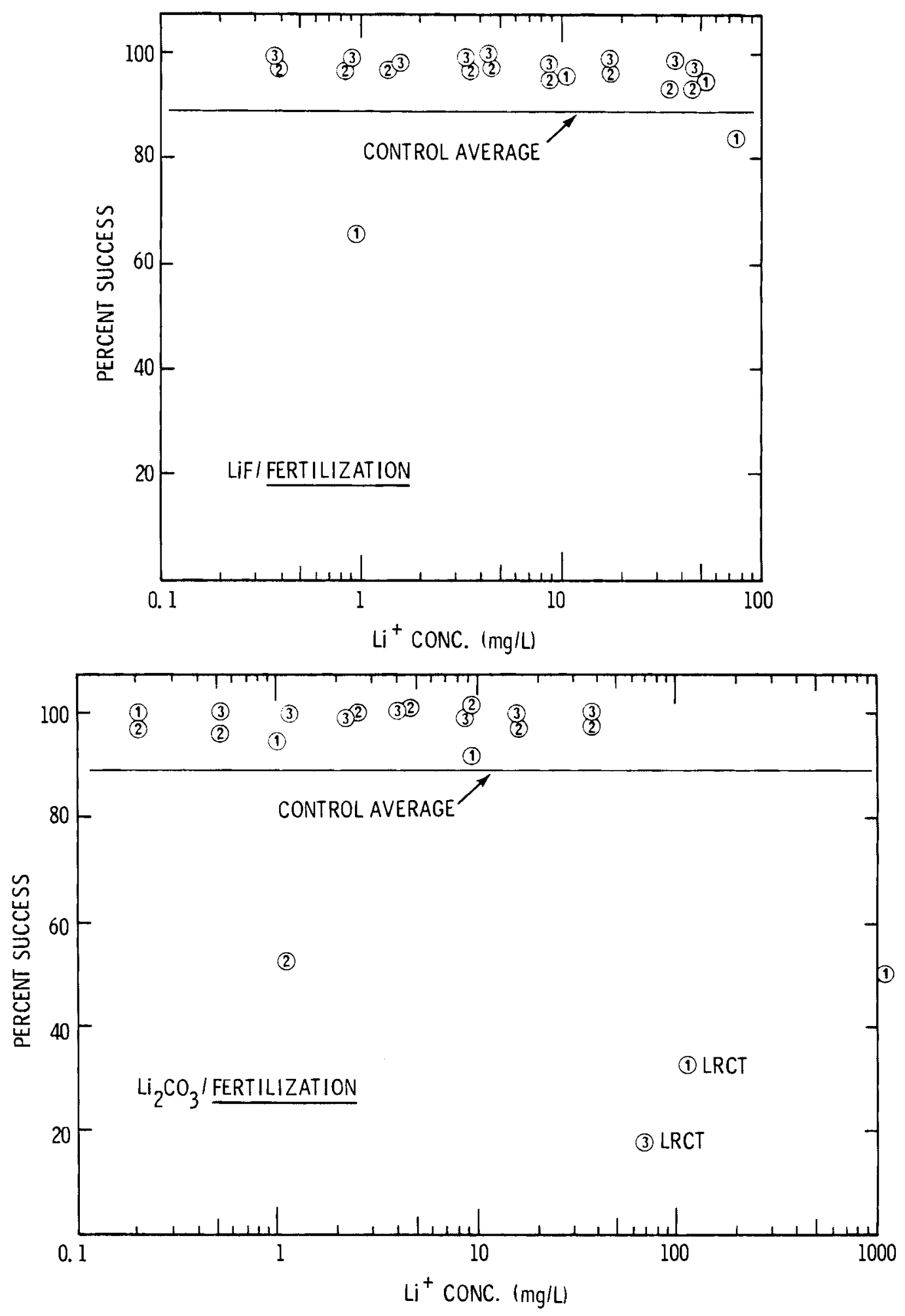

FIGURE 2. Effects of elevated $\mathrm{Li}^{+}$concentrations on trout egg fertilization. Circles display test numbers. 

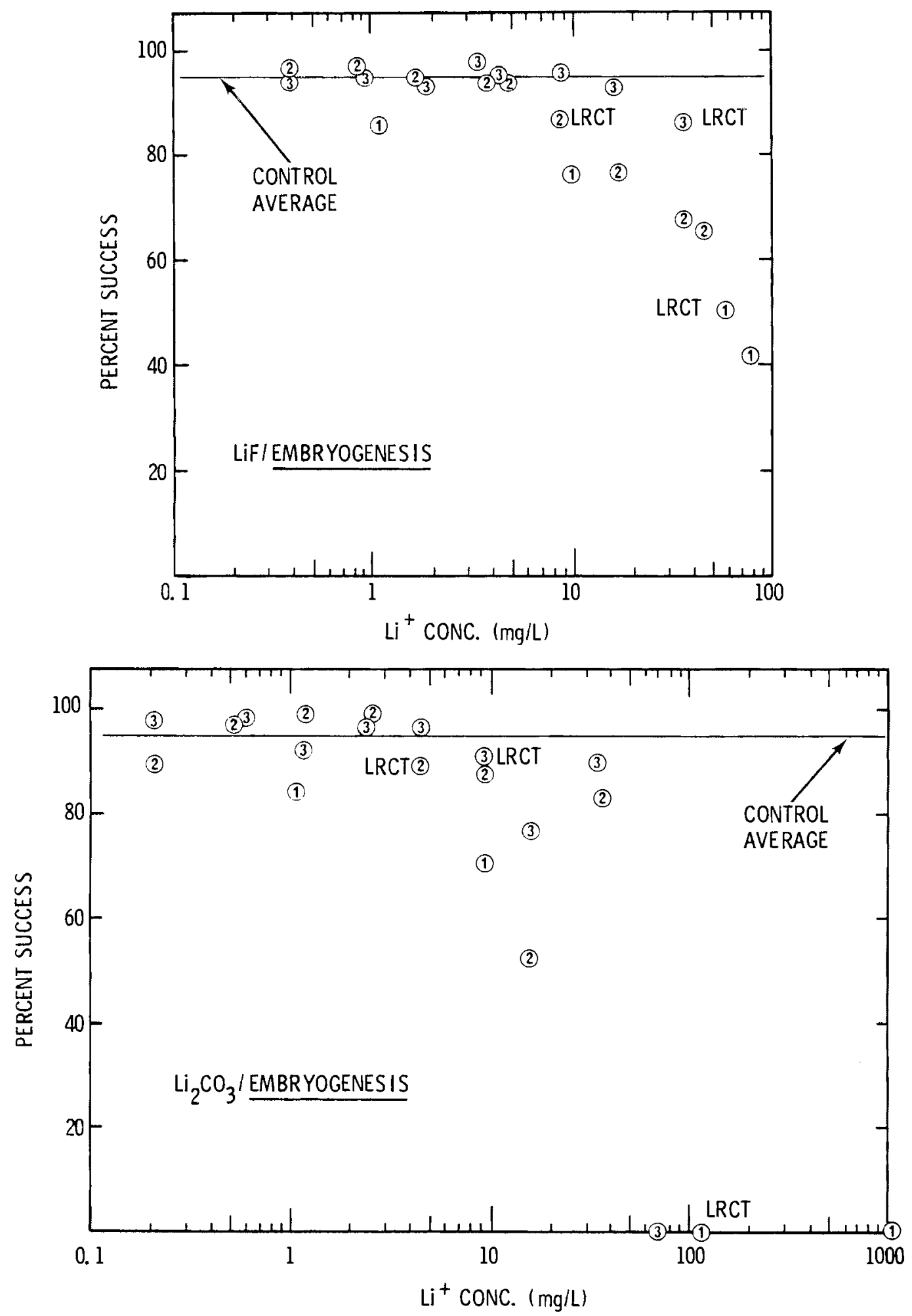

FIGURE 3. Effects of elevated $\mathrm{Li}^{+}$concentrations on the success of trout egg embryogensis. Circles display test numbers. 
Trout Egg Hatchability:

LRCTs for this parameter fell in a narrow range of 3.6 to $10.1 \mathrm{mg} \mathrm{Li}{ }^{+} / \mathrm{L}$ (Fig. 4). The consistency of these observations tends to confirm the others-$\mathrm{Li}^{+}$is incipiently toxic to trout eggs about $1 \mathrm{mg} / \mathrm{L}$.

Trout Sac-fry Survival:

LRCTs for this parameters are nearly identical to those of hatchability. They appear in a narrow range from 2.4 to $10.1 \mathrm{mg} \mathrm{Li} / \mathrm{L}(\mathrm{Fig} .5)$. Once again our observations seem confirmed.

Juvenile Trout Survival:

The range of LRCTs for this parameter is narrow $\left(0.6\right.$ to $1.3 \mathrm{mg} \mathrm{Li}{ }^{+} / \mathrm{L}$, Fig. 6). Our results show almost complete survival in $0.5 \mathrm{mg} \mathrm{Li} / \mathrm{L}$, but almost no survival above $1.0 \mathrm{mg} / \mathrm{L}$. This parameter provides evidence that $\mathrm{Li}^{+}$may be incipiently toxic below $1 \mathrm{mg} / \mathrm{L}$.

Periphyton Biomass:

Three out of the four LRCTs for this parameter are below $1 \mathrm{mg} / \mathrm{L}$ (Fig. 7). A11 are grouped in a narrow range extending from 0.3 to $1.4 \mathrm{mg} / \mathrm{L}$. These LRCTs are nearly identical to those obtained form juvenile trout bioassays. It also appears that the colonization and growth of periphytic algae is reduced in $\mathrm{Li}^{+}$ concentrations approaching $0.1 \mathrm{mg} / \mathrm{L}$.

Periphyton Photosynthesis:

This parameter seemed to show incons istaent response to elevated concentrations of $\mathrm{Li}^{+}$(Fig. 8). It's LRCTs range from 3.5 to $27.8 \mathrm{mg} \mathrm{Li} / \mathrm{L}$. Nevertheless, it appears that $\mathrm{Li}^{+}$is incipiently toxic to the photosynthetic process at concentrations approaching $1 \mathrm{mg} / \mathrm{L}$.

\section{Insect Habitation:}

The habitation of chironomid larvae was affected consistently by elevated $\mathrm{Li}^{+}$concentrations (Fig. 9). LRCTs range from 0.4 to $1.4 \mathrm{mg} \mathrm{Li} / \mathrm{L}$. These experiments have demonstrated in replication that chironomids are sensitive to $\mathrm{Li}^{+}$at concentrations approaching $0.1 \mathrm{mg} / \mathrm{L}$. 

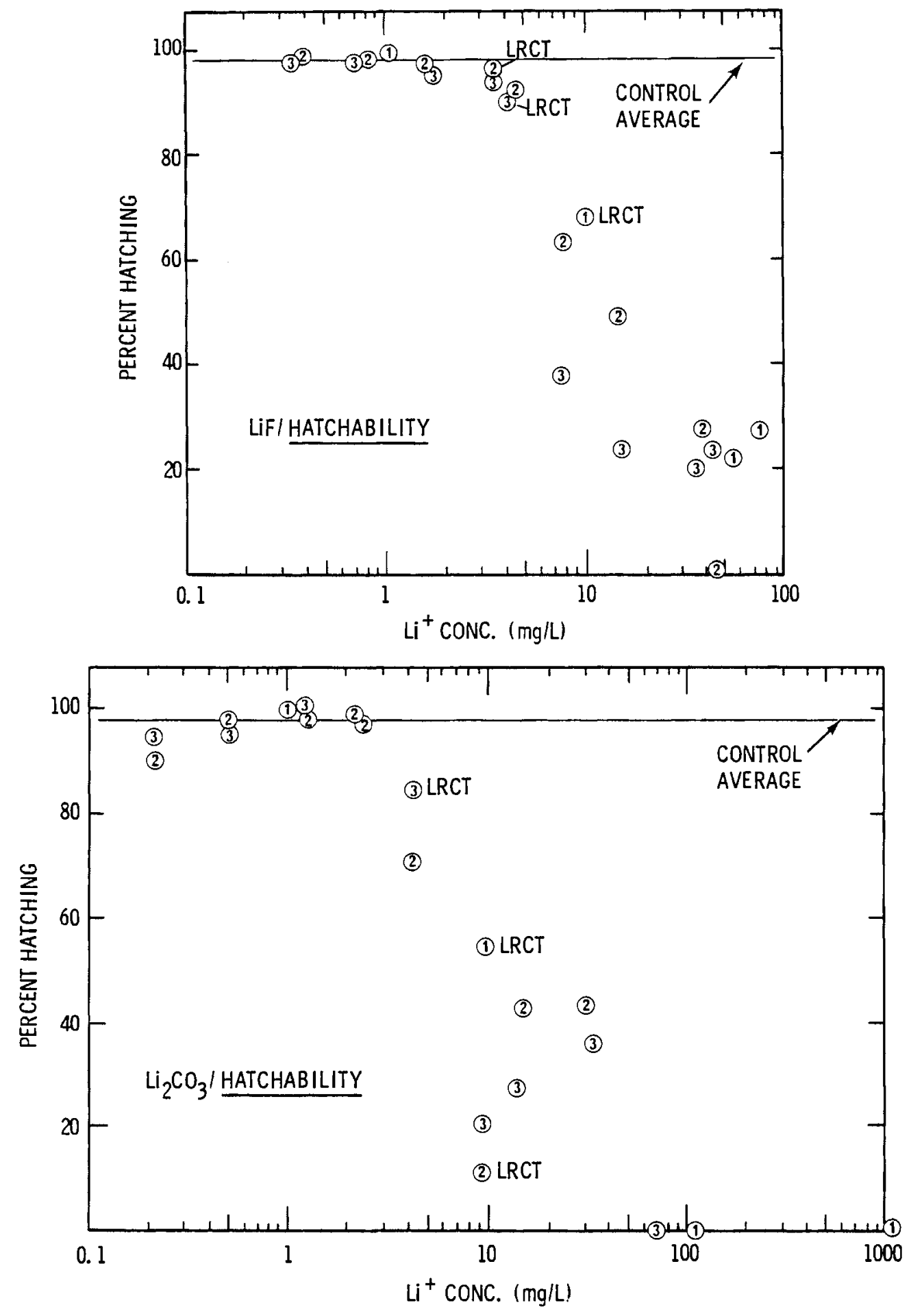

FIGURE 4. Effects of elevated $\mathrm{Li}^{+}$concentrations on hatching success of trout eggs. Circles display test numbers. 

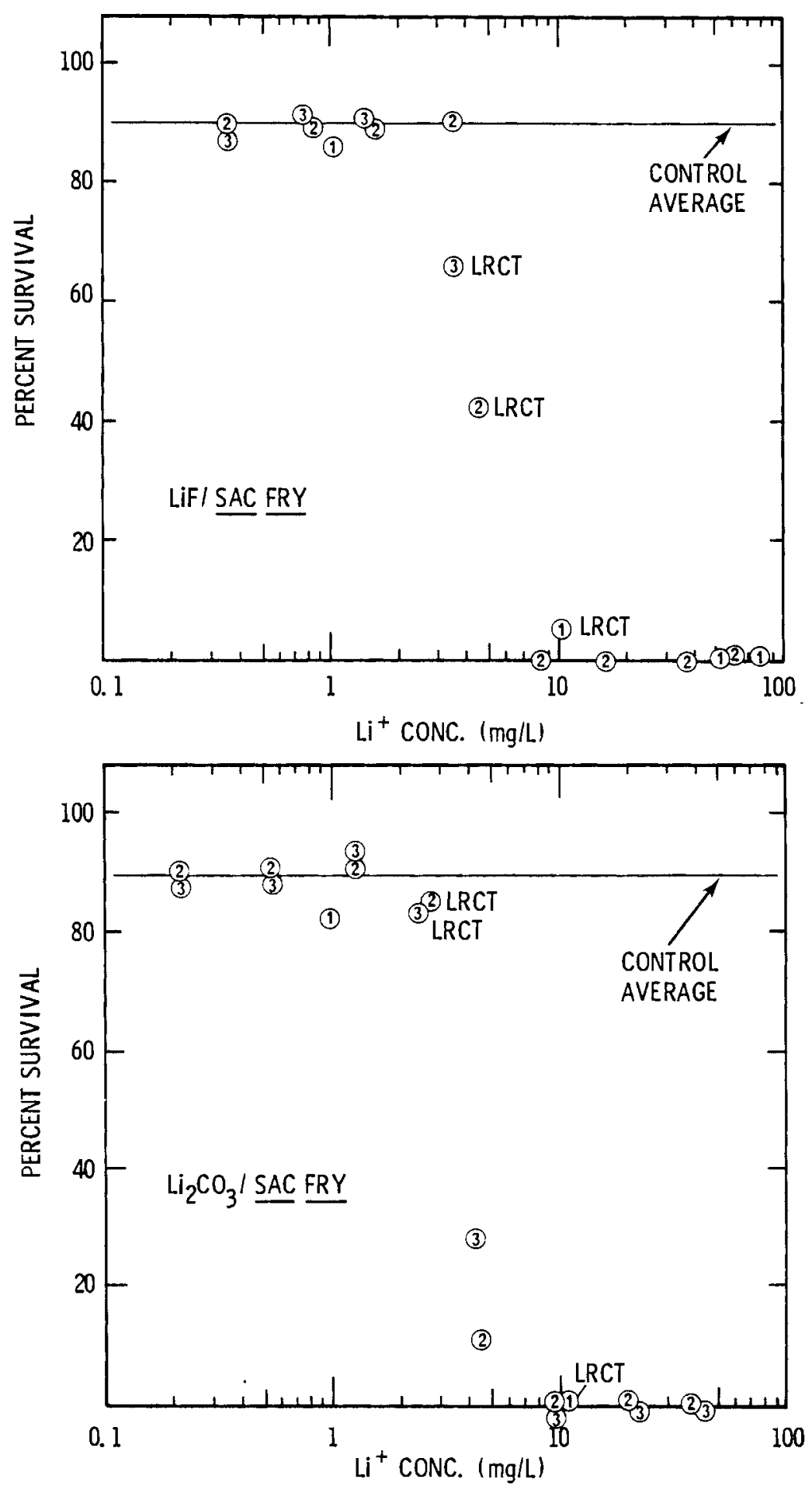

FIGURE 5. Survival of trout sac fry undergoing embryogenes is in elevated $\mathrm{Li}^{+}$concentrations. Circles display test numbers. 

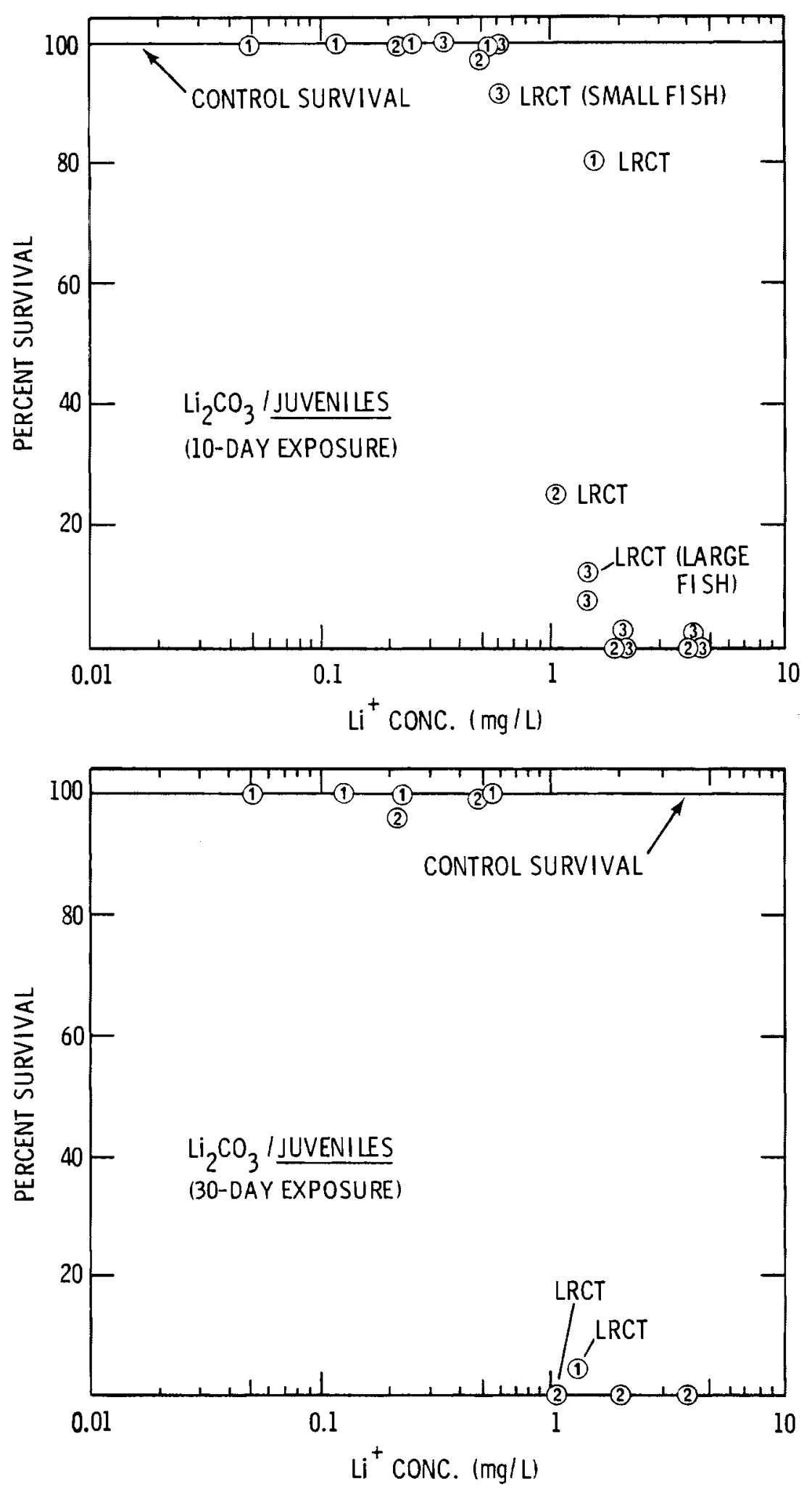

FIGURE 6 . Survival of juvenile trout in elevated $\mathrm{Li}^{+}$concentrations. Circles display test numbers. 


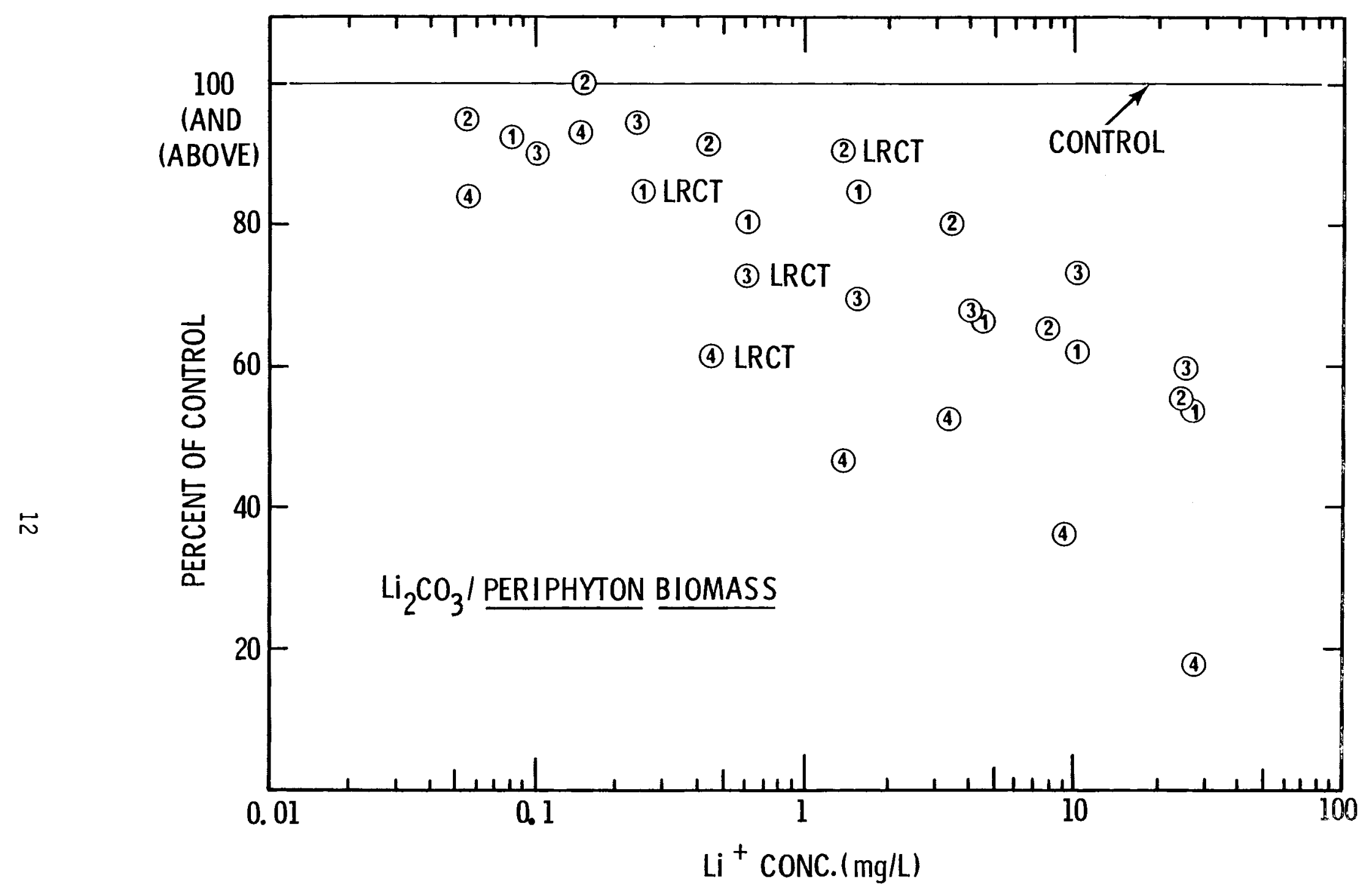

FIGURE 7. Effects of elevated $\mathrm{Li}^{+}$concentrations on relative accumulations of periphyton biomass. Circles display test numbers. 


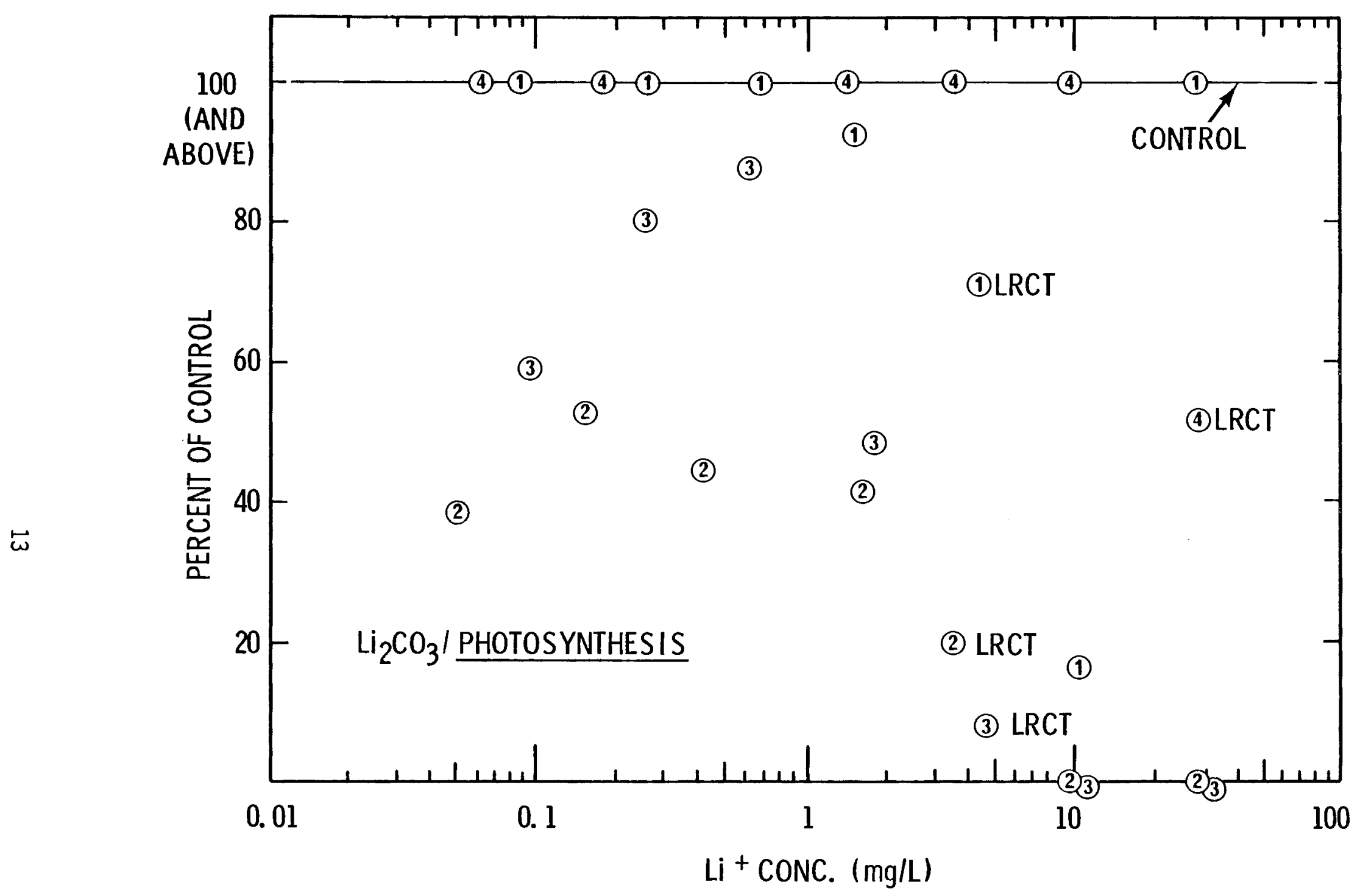

FIGURE 8. Effect of elevated $\mathrm{Li}^{+}$concentrations on relative photosynthetic rates of periphyton. Circles display test numbers. 


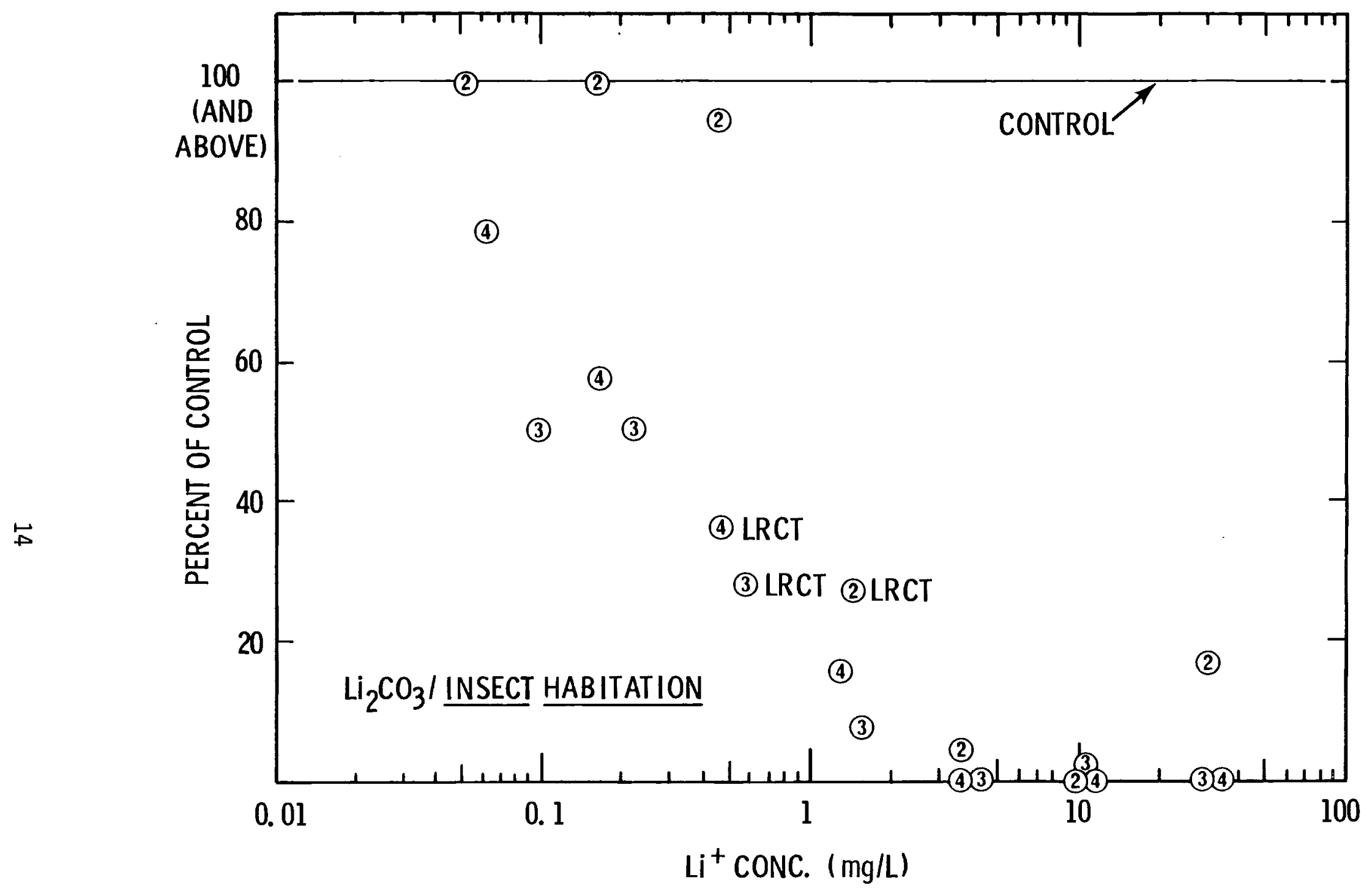

FIGURE 9. Effects of elevated $\mathrm{Li}^{+}$concentrations on the relative habitation of chironomid larvae. Circles display test numbers. 


\section{DISCUSSION}

Our LRCT concentrations appear to be the lowest $\mathrm{Li}^{+}$toxicity data reported for aquatic organisms. Only one other investigator reported data similar to ours. Angelovic (1961) reported LiF was toxic $\left(\mathrm{LO}_{50}\right)$ to rainbow trout at a molecular concentrations ranging from 5.4 to $7.5 \mathrm{mg} / \mathrm{L}$. Expressed as concentrations of $\mathrm{Li}^{+}, 1.9$ to $2.7 \mathrm{mg} / \mathrm{L}$, these results approximate our own.

There seems to be no earlier data available that defines the toxicity of $\mathrm{Li}_{2} \mathrm{CO}_{3}$ on aquatic life. King (1953), however, reported that $\mathrm{Li}_{2} \mathrm{CO}_{3}$ was toxic to the fruit fly (Drosophila) at molecular concentrations of $295-516 \mathrm{mg} / \mathrm{L}$. Expressed as concentrations of $\mathrm{Li}^{+}$, these range from 55 to $97 \mathrm{mg} / \mathrm{L}$.

There are several reports of the toxicity of $\mathrm{LiCl}$ to fish and invertebrates. Toxic concentrations of $\mathrm{LiCl}$ to fish were $>100 \mathrm{mg} / \mathrm{L}$ (Doudoroff and Katz 1953, Ellis 1937, Meinck, Stoof and Hohlshutter 1956). However, Anderson (1948) and Bringmann and Kuhn (1959) report that LiCl is toxic to Daphnia magna in a molecular concentration range of 7 to $16 \mathrm{mg} / \mathrm{L}\left(1.1\right.$ to $\left.2.6 \mathrm{mg} \mathrm{Li}^{+} / \mathrm{L}\right)$.

The few remaining reports defining $\mathrm{Li}^{+}$toxicity to aquatic life are practically uninterpretable. Their expressions of $\mathrm{Li}^{+}$toxicity all exceed $1000 \mathrm{mg} / \mathrm{L}$.

Considering all of the rainbow trout parameters, the lowest LRCT was $0.6 \mathrm{mg}$ $\mathrm{Li}^{+} / \mathrm{L}$ (juvenile survival, Table 1). Columbia River periphyton communities were affected similarily. Algae biomass was reduced at $\mathrm{Li}^{+}$concentrations of $0.3 \mathrm{mg} / \mathrm{L}$, and photosynthes is was suppressed at $3.5 \mathrm{mg} / \mathrm{L}$. These minimum LRCT observations were confirmed additionally by the habitation of chironomid larvae. They were sensitive to $0.4 \mathrm{mg} \mathrm{Li}^{+} / \mathrm{L}$.

From this it is clear that incipient toxicity to important biota in this $k$ ind of salmomid habitat falls in the range of 0.1 to $1.0 \mathrm{mg} \mathrm{Li} / \mathrm{L}$ (Fig. 10). The complete array of LRCT data, including LRCT for large and small trout, extend from 0.3 to $108 \mathrm{mg} \mathrm{Li} / \mathrm{L}$. About three-quarters of the LRCT occur below $10 \mathrm{mg} \mathrm{Li} / \mathrm{L}$ and nearly one-fifth were at or below $1 \mathrm{mg} \mathrm{Li}^{+} / \mathrm{L}$. 
TABLE 1. The LRCT expressions defining incipiently toxic concentrations of $\mathrm{Li}^{+}$for all tests and experimental parameters.

\begin{tabular}{|c|c|c|c|c|c|c|c|c|c|}
\hline \multirow[b]{3}{*}{ PARAMETER } & \multicolumn{9}{|c|}{ STATISTICALLY DEFINED LRCT CONC. $\left(\mathrm{mg} \mathrm{Li}{ }^{+} / \mathrm{L}, a=0.05\right)$} \\
\hline & \multicolumn{2}{|c|}{ TEST 1} & \multicolumn{2}{|c|}{ TEST 2} & \multicolumn{2}{|c|}{ TEST 3} & \multicolumn{2}{|c|}{ TEST 4} & \multirow{2}{*}{$\begin{array}{l}\text { LOWEST } \\
\text { LRCT }\end{array}$} \\
\hline & LiF & $\mathrm{Li}_{2} \mathrm{CO}_{3}$ & LiF & $\mathrm{Li}_{2} \mathrm{CO}_{3}$ & LiF & $\mathrm{Li}_{2} \mathrm{CO}_{3}$ & LiF & $\mathrm{Li}_{2} \mathrm{CO}_{3}$ & \\
\hline \multicolumn{10}{|l|}{ RAINBOW TROUT: } \\
\hline - EGG INTEGRITY & 76.0 & 108.0 & 8.8 & 4.6 & 4.3 & 4.6 & (b) & & 4.3 \\
\hline - FERTILIZATION & $\ldots-a^{(a)}$ & 108.0 & --- & -- & --- & 70.3 & & & 70 \\
\hline - EMBRYOGENESIS & 54.8 & 108.0 & 8.8 & 4.6 & 37.4 & 9.4 & & & 4.6 \\
\hline - HATCHABILITY & 10.1 & 10.0 & 3.6 & 9.2 & 4.3 & 4.6 & & & 3.6 \\
\hline - SAC-FRY SURVIVAL & 10.1 & 10.0 & 4.4 & 2.4 & 3.3 & 2.3 & & & 2.3 \\
\hline - JUVENILE SURVIVAL & & 1.3 & & 1.0 & & 0.6 & & & 0.6 \\
\hline COLUMBIA RIVER ORGANISMS: & & & & & & & & & \\
\hline - PERIPHYTON BIOMASS & & 0.3 & & 1.4 & & 0.6 & & 0.4 & 0.3 \\
\hline - PHOTOSYNTHETIC RATE & & 4.2 & & 3.5 & & 4.2 & & 27.8 & 3.5 \\
\hline - INSECT HABITATION & & & & 1.4 & & 0.6 & & 0.4 & 0.4 \\
\hline
\end{tabular}

(a) LRCT NOT DETECTED
(b) BLANK INDICATES NO TEST PERFORMED 


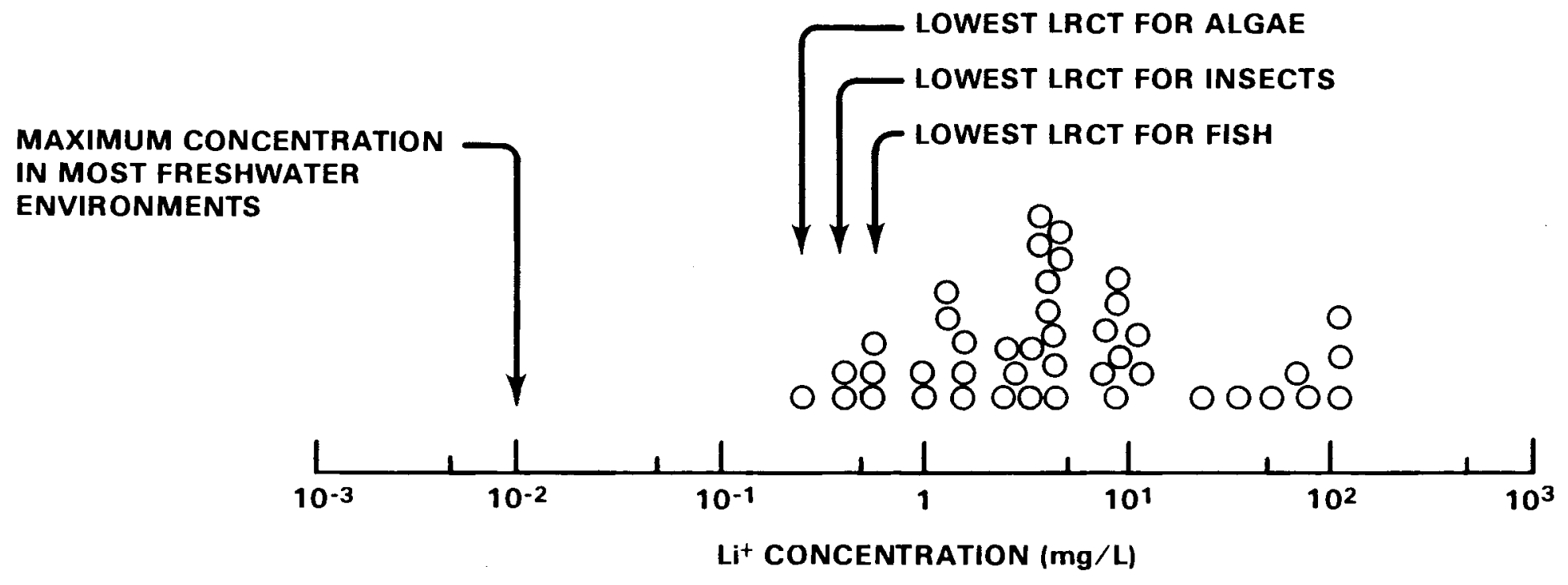

FIGURE 10. An array of a11 LRCT data from Figures 1 through 9 and Table 1. 
These results suggest that regulators of the mining, transportation, use and disposal of $\mathrm{Li}^{+}$have two key concentrations to consider for protecting most aquatic environments. These concentrations form a zone-for-regulation that is one order-of-magnitude wide. Regulators could consider $\mathrm{Li}^{+}$concentrations of $<0.01 \mathrm{mg} / \mathrm{L}$ as acceptable for nearly all aquatic systems. But concentrations $>0.1 \mathrm{mg} \mathrm{Li} / \mathrm{L}$ would create potential problems. Algae populations would begin to decline at $0.4 \mathrm{mg} / \mathrm{L}$, and trout populations at $0.6 \mathrm{mg} / \mathrm{L}$. Hence, concentrations of $\mathrm{Li}^{+}$ranging from 0.01 to $0.1 \mathrm{mg} / \mathrm{L}$ define a zone-forregulation.

Concentrations of $\mathrm{Li}^{+}>1 \mathrm{mg} / \mathrm{L}$ are certain to cause significant effects on some aquatic biota, and concentrations $>10 \mathrm{mg} \mathrm{Li} / \mathrm{L}$ could severely damage certain aquatic populations. The duration of exposure, and structural/functional characteristics of the environment exposed, would influence greatly the actual impact of $\mathrm{Li}^{+}$on biota.

A useful perspective is obtained by comparing the natural occurrence and toxicity of $\mathrm{Li}^{+}$with that of the beryllium ion $\left(\mathrm{Be}^{++}\right)$. The toxicity of $\mathrm{Be}^{++}$to aquatic life has been investigated sufficiently to allow for a comparative interpretation. Both elements have similar chemical properties and close atomic identities. Third position in the period table of elements is occupied by $\mathrm{Li}^{+}$, and $\mathrm{Be}^{++}$occupies the fourth.

Perhaps the most relevant factor in this comparison between $\mathrm{Li}^{+}$and $\mathrm{Be}^{++}$ is their common use in fusion technology. Certain core components of fusion reactors will require both elements, with $\mathrm{Be}^{++}$serving as a neutron multiplier. Hence, the mining, use and disposal of these elements will increase proportionately as fusion technology advances over the next several decades.

Today's pre-fusion demands for $\mathrm{Be}^{++}$by the U.S. are approximately $2 \times 10^{4} \mathrm{~kg} / \mathrm{yr}$ (Powell 1975)--two orders of magnitude lower than that of $\mathrm{Li}^{+}$. Contingent upon specific reactor designs, our demands for Be ${ }^{++}$could increase to $8 \times 10^{4} \mathrm{~kg} / \mathrm{yr}$ by 2000 . As construction of fusion reactors commences, demands could increase to $1 \times 10^{6} \mathrm{~kg} / \mathrm{yr}$ in 2010 . Demands for Be ${ }^{++}$will probably level off by 2030 at a rate of $1.5 \times 10^{6} \mathrm{~kg} / \mathrm{yr}$--about one-tenth of 
projected demands for $\mathrm{Li}^{+}$. Powell (1975) points out that the types of fusion reactors actually used, and the likely changes in reactor design, may alter these demand projections considerably.

The most assessable $\mathrm{Be}^{++}$deposit is in Utah. This is associated with the mineral bertrandite at Topaz Mountain. Powell (1975) concludes that this "is now the most important commercial beryllium ore deposit in the world." Utah will also supply fusion technology with $\mathrm{Li}^{+}$from its salt lakes.

In aquatic environments $\mathrm{Be}^{++}$is rarer than $\mathrm{Li}^{+}$. Beryllium occurs naturally in freshwater environments only at very low concentrations $(<0.001 \mathrm{mg} / \mathrm{L})$. A USGS study of numerous water supplies in the U.S. reported only one sample with detectable $\mathrm{Be}^{++}(0.00075 \mathrm{mg} / \mathrm{L}$, Durfor and Becker 1964). In freshwaters of California, Be ${ }^{++}$concentrations were consistently below detectability $(<0.0003 \mathrm{mg} / \mathrm{L}$, Silvey 1967). Hem (1970) suggests that natural concentrations of $\mathrm{Be}^{++}$in freshwaters are extremely low because it occurs in particulate rather than in dissolved form. However, there is a consensus of opinion that if $\mathrm{Be}^{++}$enters freshwater environments as a result of fusion technology, it would appear as a sulfate $\left(\mathrm{BeSO}_{4}\right)$. This form is more soluble than naturallyoccurring $\mathrm{Be}^{++}$ores.

The toxicity of $\mathrm{Be}^{++}$to freshwater organisms has been investigated most thoroughly by researchers at the Aerospace Medical Research Laboratory, WrightPatterson Air Force Base, near Dayton, Ohio. They have exposed both fish and amphibians to elevated Be ${ }^{++}$concentrations. Slonim and Slonim (1973) exposed the common guppy (Lebistes reticulatus), and Slonim and Ray (1975) the salamander larvae (Ambystoma spp.), to $\mathrm{BeSO}_{4}$ solutions in soft and hard water.

Using 96-hour exposure tests, they found that $\mathrm{Be}^{+\tau}$ in soft water (hardness = $22 \mathrm{mg} / \mathrm{L}$ as $\mathrm{CaCO}_{3}$ ) was 100 times more toxic than hard water solutions (hardness = $400 \mathrm{mg} / \mathrm{L})$. Median tolerance limits in soft-water Be ${ }^{++}$solutions were 0.1 to $0.3 \mathrm{mg} / \mathrm{L}$, while $\mathrm{TL}_{\mathrm{m}}$ 's in hard water were 20 to $22 \mathrm{mg} \mathrm{Be}{ }^{++} / \mathrm{L}$. Our lowest LRCT data defining $\mathrm{Li}^{+}$toxicity correspond with the lowest of these $\mathrm{TL}_{\mathrm{m}}$ concentrations. [Experiments with $\mathrm{Li}^{+}$performed in soft water (hardness $=70 \mathrm{mg} / \mathrm{L}$ ) showed incipient toxicity occurring between 0.1 and $1 \mathrm{mg} / \mathrm{L}$.$] In all \mathrm{Be}^{++}$tests where hardness exceeded $100 \mathrm{mg} / \mathrm{L}, \mathrm{TL}_{\mathrm{m}}$ concentrations were $>1 \mathrm{mg} / \mathrm{L}$. 
Results of these studies were consistent with the findings of Tarzwell and Henderson (1960) who tested common guppies, minnows (Pimephales promelas) and sunfish (Lepomis macrochirus) in softand hard-water solutions of $\mathrm{BeSO}_{4}{ }^{\cdot}$ All other investigators of $\mathrm{Be}^{++}$toxicity have reported higher toxic thresholds. The incipient toxicity of $\mathrm{Be}^{++}$appears to be comparable to that of $\mathrm{Li}^{+}$in soft water. But maximum concentrations of $\mathrm{Be}^{++}$occurring naturally in freshwaters are one order of magnitude lower than those of $\mathrm{Li}^{+}$. These observations suggest a range of 0.001 to $0.1 \mathrm{mg} \mathrm{Be}{ }^{++} / \mathrm{L}$ as "approaching toxic concentrations."

Additionaliy important are the observations of reduced toxicity in hardwater solutions of $\mathrm{Be}^{++}$. Although there is no experimental evidence, the toxicity of $\mathrm{Li}^{+}$may be reduced similarily in hard water. Hardness concentrations might be increased artificially in some freshwater environments as a treatment for accidental spills of $\mathrm{Li}^{+}$or $\mathrm{Be}^{++}$.

\section{SUMMARY AND CONCLUSION}

This study has investigated the toxicity of $\mathrm{Li}^{+}$to important components of a salmonid community typical of the Columbia River basin. Our expressions of toxic $\mathrm{Li}^{+}$concentrations are lower than any reported in the literature. We have identified concentrations of $\mathrm{Li}^{+}$that are incipiently toxic (LRCTS) to critical stages in the development of rainbow trout. We have also identified LRCTs for the accumulation of biomass and photosynthetic activity of Columbia River periphyton. And in addition, we identified LRCTs for the habitation of insect (chironomid) larvae.

Concentrations of $\mathrm{Li}^{+}$greater than $0.1 \mathrm{mg} / \mathrm{L}$ affected all of our test parameters (Fig. 10). We must conclude, therefore, that some freshwater populations could begin to decline as $\mathrm{Li}^{+}$concentrations approached $1 \mathrm{mg} / \mathrm{L}$. Beyond $1 \mathrm{mg} \mathrm{Li} i^{+} / \mathrm{L}$, certain and significant biological effects could be expected to occur in both plant and animal populations.

A comparison of these results with data defining the toxicity of $\mathrm{Be}^{++}$, a chemically similar component of fusion reactor cores, indicates that incipiently toxic concentrations of both elements correspond. However, $\mathrm{Li}^{+}$occurs more abundantly than $\mathrm{Be}^{++}$in aquatic environments. 
Since most freshwater environments can tolerate $\mathrm{Li}^{+}$concentrations of $\leq 0.01 \mathrm{mg} / \mathrm{L}$, our results suggest that regulators of the $\mathrm{Li}^{+}$economy consider a range of 0.01 to $0.1 \mathrm{mg} / \mathrm{L}$ as "approaching toxic concentrations".

\section{ACKNOWLEDGEMENT}

For their participation in this research, we wish to thank Steven Barraclough, Robert Genoway, and Ted Poston of the Ecological Sciences Department, and Kathi Hanson and Roger Schirmer of the Biology Department, here at Pacific Northwest Laboratory. 


\section{REFERENCES}

American Public Health Association, American Water Works Association, Water Pollution Control Federation. 1971. Standard Methods for the Examination of Water and Waste Water. Amer. Pub. Health Assoc., Washington, DC.

Anderson, B. G. 1948. The apparent thresholds of toxicity of Daphnia magna for chlorides of various metals when added to Lake Erie water. Trans. Amer. Fish. Soc., 78:96.

Angelovic, J. W. et al. 1961. Temperature and fluoros is in rainbow trout. J. Water Pollut. Control Fed., 33:371.

Bringmann, G. and R. Kuhn. 1959. The toxic effects of waste water on aquatic bacteria, algae, and small crustaceans. Gesundheits Ing., 80:115.

Cowgill, V. M. 1976. "The effect of the thermal regime on the annual distribution of selected elements in Linsley Pond (North Bradford, Connecticut)." In: Environmental Biochemistry, Proc. of the Isoken. Symp. 2:731-741.

Doudoroff, P. and M. Katz. 1953. Critical review of literature on the toxicity of industrial wastes and the compentents to fish, Il. The metals and salts. Sewage and Industrial Wastes, 25:802.

Durfor, C. N., and E. Becker. 1964. Public water supplies of the 100 largest cities in the United States, 1962. U.S. Geol. Survey Water Supply Paper 1812, Washington, D.C.

Durum, W. H., and J. Haffty. 1961. Occurrence of minor elements in water. U.S. Geol. Survey Circ. 445, Washington, D.C.

Ellis, M. M. 1937. Detection and measurement of stream pollution (related principally to fish life). U.S. Dept. of Commerce, Bur. of Fisheries Bull. 22, washington, D.C.

Emery, R. 1981. The relevance of ecological theory to environmental hazard assessments. Battelle, Pacific Northwest Laboratory, PNL-SA-9274, Richland, Washington.

Hem, J. D. 1970. Study and interpretation of the chemical characteristics of natural waters. U.S. Geol. Survey Water Supply Paper 1473, 2nd ed., Washington, D.C.

King, R. C. 1953. Effects of alkali metal ions on development of Drosophila, with special reference to lithium induced abnormalities. Proc. National Acad. Sci., 39:403.

Leitritz, E. and R. C. Lewis. 1976. Trout and salmon culture (hatchery methods). State of California, Dept. Fish and Game, Fish Bull. 164, Sacramento, California. 
Meinck, F., H. Stoof and H. Hohlshutler. 1956. Industrie Agwasser (Industrial Waste Waters). 2nd Ed., Gustar Fisher Verlag, Stuttgart 536, 44 D. $\bar{M}$.

Mount, D. I., and W. A. Brungs. 1967. A simplified dosing apparatus for fish toxicology studies. Water Research 1:21-29.

Powe11, J. R. 1975. Beryllium and lithium resource requirements for solid blanket designs for fusion reactors. Brookhaven National Lab., BNL-20299, Long Island, New York.

Silvey, W. D. 1967. Occurrence of selected minor elements in the waters of California. U.S. Geol. Survey Water Supply Paper 598, Washington, D.C.

Skalski, J. R. 1981. Statistical inconsistencies in the use of no observed-effect levels in toxicity tests. In: Aquatic Toxicology and Hazard Assessment, Fourth Conference, ASTM STP $7 \overline{37}$, D. R. Branson and K. L. Dickson, Eds. American Society for Testing and Materials, pp. 377-387.

Slonim, C. B. and A. R. Slonim. 1973. Acute toxicity of beryllium sulfate to the common guppy. Journal Water Pollut. Contr. Fed. 45:2110-2122.

Slonim, C. B. and E. E. Ray. 1975. Acute toxicity of beryllium sulfate to salamander larvae (Ambystoma spp.). Envir. Contam. and Tox. 13:307-312.

Tarzwel1, C. M. and C. Henderson. 1960. Toxicity of less common metals to fishes. Industrial Wastes 5:12.

U.S. Environmental Protection Agency. 1976. Quality Criteria For Water. Washington, D.C.

U.S. Federal Water Pollution Control Administration. 1968. 1968 Report of the Committee on Water Quality Criteria. Washington, D.C.

Varian Techtron. 1971. Analytic Methods for Flame Spectroscopy. Varian Techtron, Ltd., Melbourne, Australia.

Verduin, J. 1964. Principles of primary productivity: photosynthesis under completely natural conditions. In: Algae and Man, E. F. Jackson, ed., Proc. NATO Advanced Study Inst., 1962, LouisviTle, KY, Plenum Press, NY, pp. 221-238.

Vine, J. D. (ed.). 1976. Lithium Resources and Requirements by the Year 2000. Proc. of Golden, Colorado, Conf., U.S. Geol. Survey Paper 1005, Golden, Colorado. 


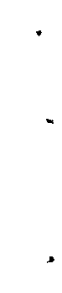

-

, 
APPENDIX A

EXPERIMENTAL METHODS 
APPENDIX A

\section{EXPERIMENTAL METHODS}

\subsection{RAINBOW TROUT EXPERIMENTS}

\subsection{EARLY DEVELOPMENTAL STAGES}

To observe effects of elevated concentrations of $\mathrm{Li}^{+}$on trout egg integrity, fertilization, embryogenesis, and hatchability, we used the recirculating exposure chambers shown in Figure Al. Each system contained $9 L$ of water and recirculated that volume once every $6 \mathrm{hr}$. This size and amount of circulation permitted excellent development of up to 1000 eggs in control chambers. In all trout egg experiments, we used four replicated bioassay chambers at each test concentration of $\mathrm{Li}^{+}$. The total number of eggs at each test concentration was distributed equally among the replicates.

\subsubsection{Chemical Parameters}

Test solutions of $\mathrm{Li}^{+}$were prepared by diluting batch concentrations to the intended concentrations identified in Tables A1 through A3. Concentrations of $\mathrm{Li}^{+}$in the water of these test chambers were monitored evey 48 hours throughout these 30- to 40-day test periods. These $\mathrm{Li}^{+}$concentrations were measured on a Varian Model AA6 flame atomic absorption spectrometer. These analyses were performed by PNL's Analytic Chemistry Group, Biology Department, using techniques described by Varian Techtron (1971).

Temperatures of these experimental systems were maintained by a $10^{\circ} \mathrm{C}$ water bath. Each test unit (Figure A1) rested three-fourths in one of two large water baths. Temperatures were monitored continuously using a Yellow Springs Instruments (YSI) Mode $181 \mathrm{~A}$ temperature recorder.*

Additional data were also collected from test and control systems weekly. Measurement of dissolved oxygen were made using a YSI DO probe and Model 51A meter. An Orion Research Model 901 ionalyzer meter was used to measure $\mathrm{pH}$.

ऋ Trade name specification does not imply endorsement by PNL or DOE. 


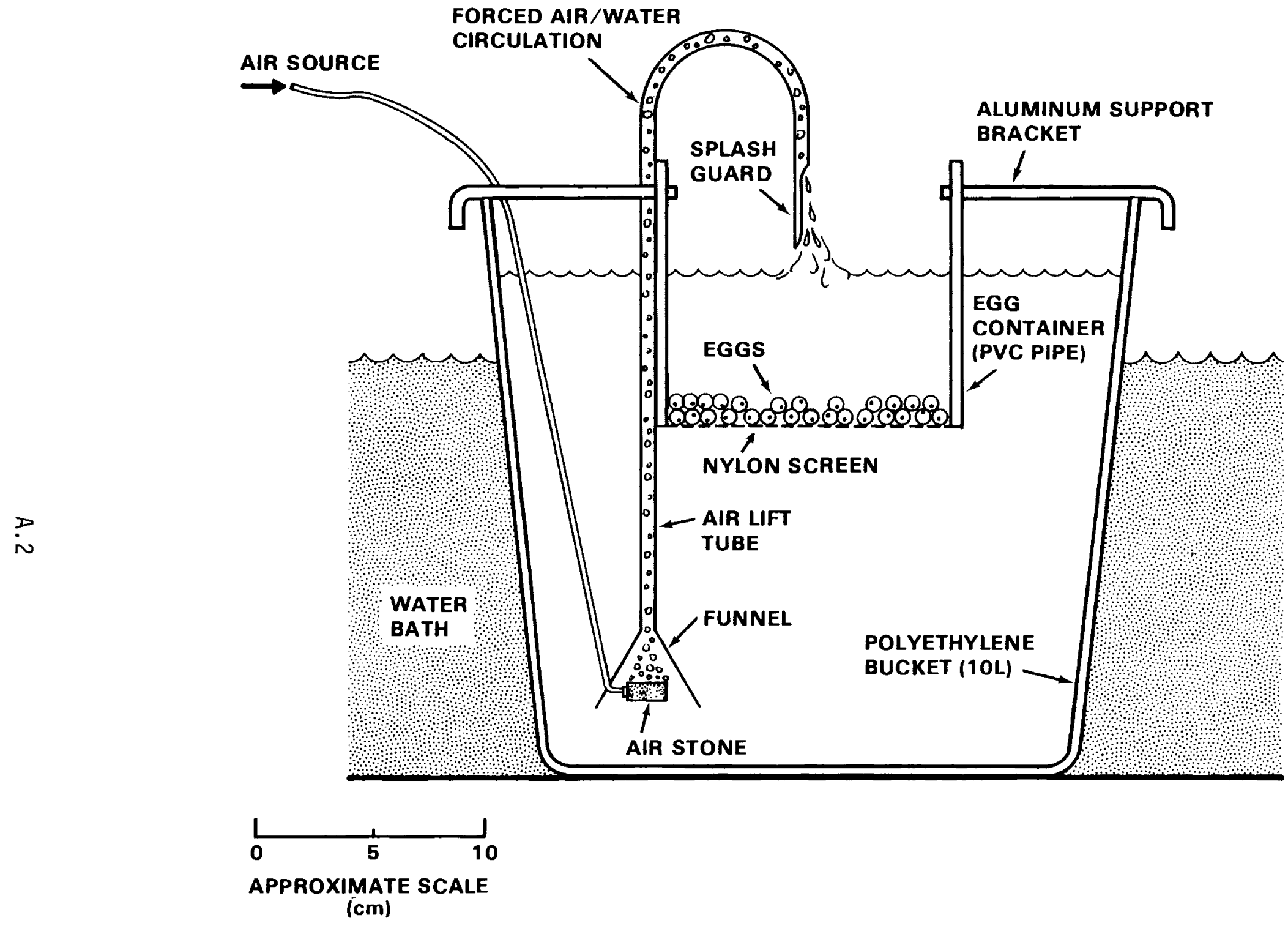

FIGURE A1. A recirculating exposure chamber for testing trout egg development in elevated $\mathrm{Li}+$ concentrations. 
TABLE A1. Experimental conditions and results of the first test where early stages of trout development were exposed to elevated concentrations of $\mathrm{Li}^{+}$. Results producing LRCTs are enclosed in boxes.

TEST 1:

PARAMETERS

INTENDED Li ${ }^{+}$EXPOSURE CONC. (mg/L)

MEASURED Li ${ }^{+}$CONC. (mg/L) - MEAN - \pm c.i. (a) - (n) (b)

TEST DURATION (DAYS/DATES)

TEMPERATURE (RANGE, ${ }^{\circ} \mathrm{C}$ )

DISSOLVED OXYGEN (RANGE, mg/t)

PH (RANGE)

i

TOTAL ALKALINITY (RANGE, mg/L AS $\mathrm{CaCO}_{3}$ )

TOTAL HARDNESS (RANGE, mg/L AS $\mathrm{CaCO}_{3}$ )

EGG INTEGRITY $\left(\frac{\text { VIABLF EGGS }}{\text { TOTALEGGS }}\right)$

FERTILIZATION ( $\left.\frac{\text { FERTILIZED EGGS }}{\text { VIABIFEGGS }}\right)$

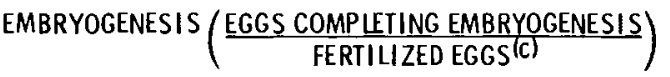

HATCHABILITY ( $\left.\frac{\text { EGGS HATCHING }}{\text { EGGS COMPLETING EMBRYOGENESIS ICI) }}\right)$

SAC-FRY SURVIVAL (ERY SURVIVAL TO BUITON-UP $)$

EXPERIMENTAL CONDITIONS

\begin{tabular}{|c|c|c|c|c|c|c|c|c|}
\hline \multirow{2}{*}{$\begin{array}{c}\text { CONTROL } \\
0.0 \\
\end{array}$} & \multicolumn{4}{|c|}{ LIF SOLUTIONS } & \multicolumn{4}{|c|}{$\mathrm{Li}_{2} \mathrm{CO}_{3}$ SOLUTIONS } \\
\hline & 1.0 & 10.0 & 70.0 & SATURATION & 1.0 & 10.0 & 100.0 & 1000.0 \\
\hline $\begin{array}{c}<0.01 \\
--- \\
(12)\end{array}$ & $\begin{array}{r}1.03 \\
\pm 0.10 \\
(12)\end{array}$ & $\begin{array}{r}10.00 \\
\pm 0.60 \\
(12)\end{array}$ & $\begin{array}{r}54.81 \\
\pm 4.70 \\
(12)\end{array}$ & $\begin{array}{r}76.0 \\
\pm 6.67 \\
(12)\end{array}$ & $\begin{array}{r}1.01 \\
\pm 0.09 \\
(12)\end{array}$ & $\begin{array}{r}9.97 \\
\pm 0.73 \\
(12)\end{array}$ & $\begin{array}{c}108.0 \\
\pm 6.30 \\
(6)\end{array}$ & $\begin{array}{c}1071.0 \\
\pm 40.5 \\
(3)\end{array}$ \\
\hline & & & TO HATC & & $.5 \mathrm{TO}$ BUT & ON-UP & & \\
\hline 9.3-10.3 & $9.3-10.2$ & $9.1-10.2$ & $9.4-10.2$ & $8.7-10.5$ & $9.6-10.4$ & $7.7-103$ & $10.1-10.5$ & $10.0-10.1$ \\
\hline $7.6-8.2$ & $7.8-8.1$ & $7.8-8.2$ & $7.7-8.3$ & $7.7-8.2$ & $7.8-8.5$ & $7.7-9.0$ & $9.7-10.6$ & $10.9-11.0$ \\
\hline & & & XPER & IMENTAL & RESUL & & & \\
\hline$\frac{2995}{3051}$ & $\frac{1004}{1007}$ & $\frac{1063}{1069}$ & $\frac{1188}{1201}$ & \begin{tabular}{|l|}
1180 \\
1208 \\
\end{tabular} & $\frac{1060}{1066}$ & $\frac{1074}{1080}$ & $\frac{775}{1003}$ & $\frac{1075}{1122}$ \\
\hline$\frac{2557}{2995}$ & $\frac{942}{1004}$ & $\frac{1024}{1063}$ & $\frac{1136}{1188}$ & $\frac{995}{1180}$ & $\frac{1004}{1060}$ & $\frac{994}{1074}$ & $\frac{268}{775}$ & $\frac{552}{1075}$ \\
\hline${\frac{1310^{(0)}}{2122}}^{(1)}$ & $\frac{628}{725}$ & $\frac{612}{787}$ & $\frac{448}{882}$ & $\frac{289}{679}$ & $\frac{660}{781}$ & $\frac{574}{808}$ & $\frac{0}{250}$ & $\frac{0}{552}$ \\
\hline$\frac{1295}{1310}$ & $\frac{626}{628}$ & $\frac{417}{612}$ & $\frac{101}{448}$ & $\frac{77}{289}$ & $\frac{657}{660}$ & $\frac{316}{574}$ & $-0-$ & $-0-$ \\
\hline$\frac{993}{1099}$ & $\frac{478}{554}$ & $\frac{28}{394}$ & $\frac{0}{101}$ & $\frac{1}{77}$ & $\frac{508}{615}$ & $\frac{5}{316}$ & $-0-$ & $-0-$ \\
\hline
\end{tabular}

(a) STATISTICAL CONFI DENCE INTERVAL ABOUT THE MEAN AT $a=0.05$

(b) NUMBER OF OBSERVATIONS

(c) SOME EGGS WERE SUBSAMPLED AND PRESERVED OR LOST DURING ANALYTIC PROCEDURES

(d) ACCI DENTAL LOSSES OF SOME CONTROL EGGS 
TABLE A2. Experimental conditions and results of the second test where early stages of trout development were exposed to elevated $\mathrm{Li}^{+}$concentrations. Results producing LRCTs are enclosed in boxes.

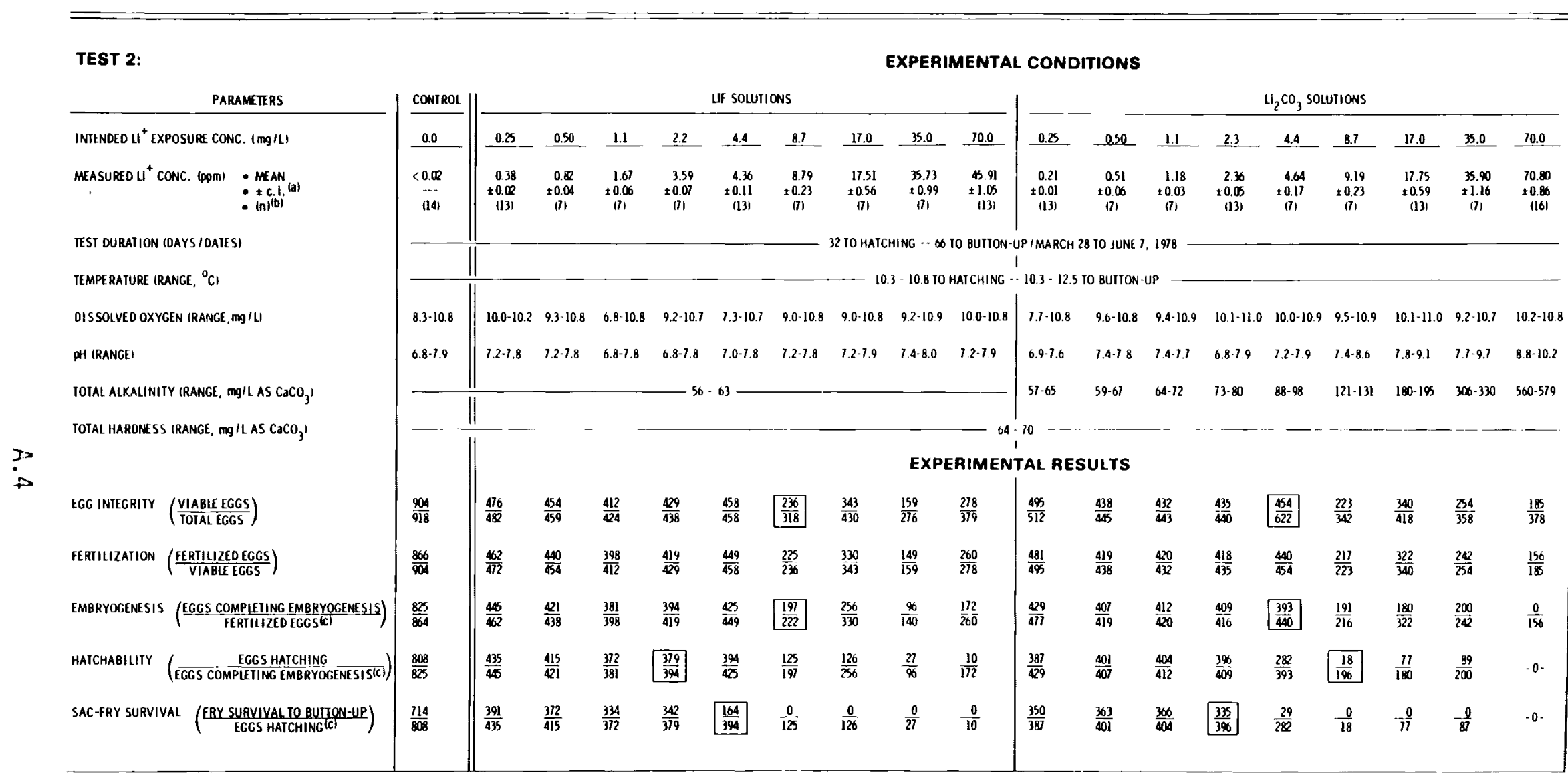

(a) SIAIISTICAL CONFIDENCE INIERVAL ABOUI IHE MEAN AT $\alpha=0.05$

ICISOME EGGS WEER SUB SAMPLED AND PRE SERVED OR LOST DURING ANALVIIC PROCEDURES 
TABLE A3. Experimental conditions and results of the third test where early stages of trout development were exposed to elevated $\mathrm{Li}^{+}$concentrations. Results producing LRCTs are enclosed in boxes.

TEST 3:

EXPERIMENTAL CONDITIONS

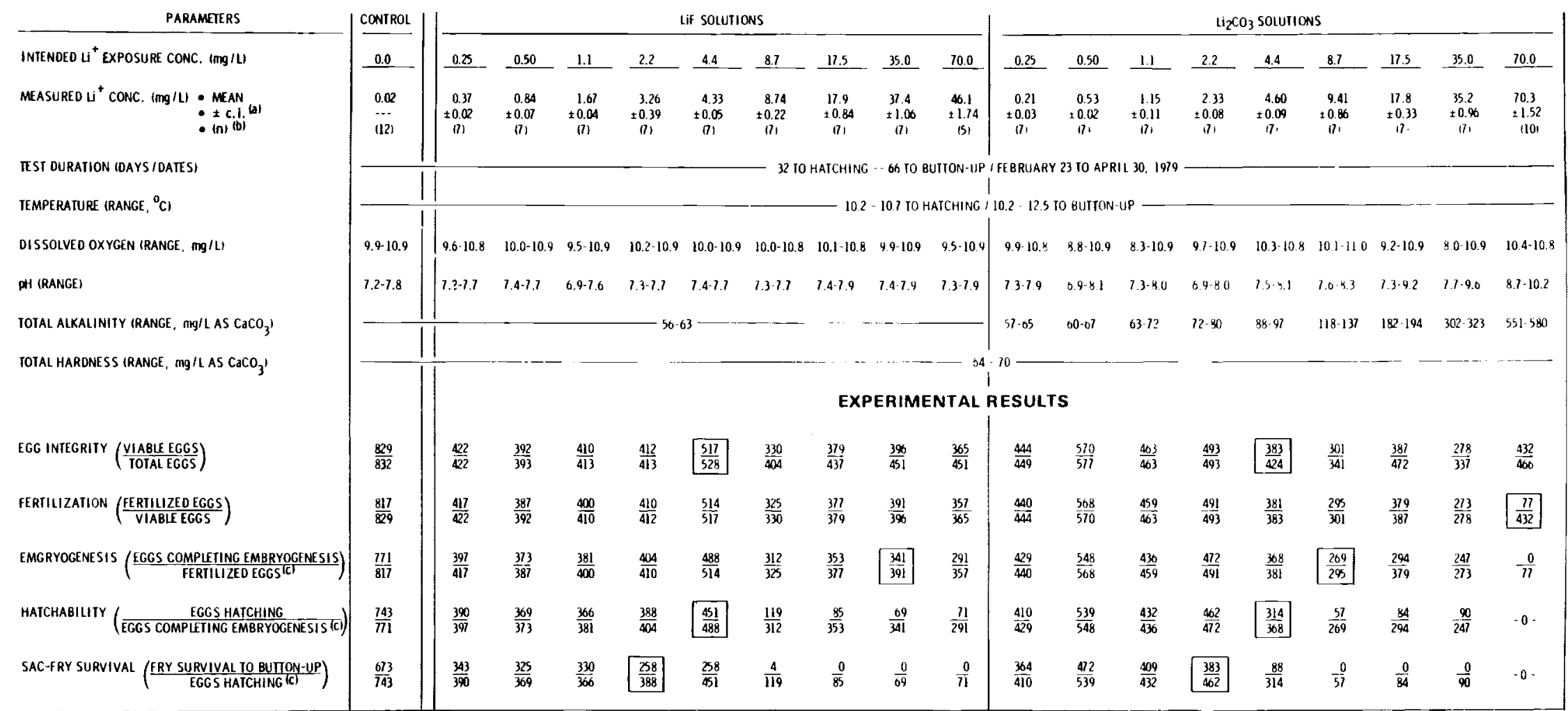

(6) STATISTICAL CONF I DENCE INTERVAL ABOUT THE MEAN AT a $=0.05$

(6) NUMBER OF OBSERVATIONS
(c) SOME EGGS WERE SUBSAMPLED ANO PRESERVED OR LOST DURING ANALTIC PROCEDURES 
Alkalinity and hardness (expressed as $\mathrm{ppm} \mathrm{CaCO}_{3}$ ) were determined titrametrically by methods described in Standard Methods (APHA et al. 1971). Both alkalinity and hardness exist within narrow ranges in Columbia River water (56 to $63 \mathrm{mg} / \mathrm{L}$ and 64 to $70 \mathrm{mg} / \mathrm{L}$, respectively).

Trout eggs bioassays were performed in both $\mathrm{LiF}$ and $\mathrm{Li}_{2} \mathrm{CO}_{3}$ solutions. Upper concentrations of $\mathrm{Li}^{+}$from LiF were limited to $\leq 80 \mathrm{mg} / \mathrm{L}$ due to its saturation in Columbia River water. However, we were able to prepare $\mathrm{Li}_{2} \mathrm{CO}_{3}$ solutions with $\mathrm{Li}^{+}$concentrations of 100 and $1000 \mathrm{mg} / \mathrm{L}$.

A11 expressions of toxicity are based on the measured concentrations in Tables $A 1$ through $A 3$, and are expressed as $\mathrm{mg}$ of $\mathrm{Li}^{+} / \mathrm{L}$.

\subsubsection{Biological Parameters}

Egg integrity (I) was defined by the ratio

$$
I=\frac{\sum i-b}{\sum i},
$$

where $\Sigma i$ is the total number of eggs incubated and $b$ is the number of eggs with broken protective membranes (macroscopically observable). All broken eggs were removed from experimental incubators.

Fertilization success $(F)$ was determined using the equation

$$
F=\frac{\sum f}{\sum i-b}
$$

where $\Sigma f$ is the total number of fertilized eggs. This includes both the eggs entering embryogenesis (obviously fertile and not disturbed) and fertile eggs dying before embryonic formation. At this stage of our experiments, dead eggs were immediately preserved and later examined for evidence of fertilization. This was done microscopically by identifying early formations of blastodiscs in successfully fertilized eggs (Leitritz and Lewis 1976). 
Completion of embryogenes is (E) was determined with the equation

$$
E=\frac{\Sigma e}{(\Sigma f)-e_{s}},
$$

where $\Sigma e$ is the total number of eggs completing embryogenesis, and $e_{s}$ is the number of eggs sub-sampled prior to completion of embryogenesis.

Hatchability $(H)$ was determined using the ratio

$$
H=\frac{\sum h}{\sum e},
$$

where $\sum h$ is the total number of eggs hatching successfully.

Sac-fry survival (S) is defined by the equation

$$
S=\frac{\Sigma S}{(\Sigma h)-s_{S}} \text {, }
$$

where $\Sigma s$ is the total number of sac fry that survived to their "button-up" stage and $s_{s}$ is the number of sac fry sub-sampled and preserved. The term "button-up" is a commonly accepted expression that depicts the sealing of a ventral integument where the yolk sac had once protruded (Leitritz and Lewis 1976). This marks the beginning of fryhood.

It was not possible to maintain these sac fry in the recirculating test chambers where they had undergone embryogenesis (Figure Al). Sac fry require a continuous passage of much larger volumes of water for development to occur. This was provided by passing Columbia River water through hatchery troughs. Sac fry were transferred to these stream conditions after hatching. Experimental quantities of $\mathrm{Li}^{+}$were not added to these troughs. The required large volumes of single-passing river water prohibited direct $\mathrm{Li}^{+}$bioassays here. However, parameter $S$ expresses the ability of rainbow trout fry to button-up after they had been exposed to $\mathrm{Li}^{+}$contamination during previous developmental stages. 


\subsection{JUVENILES}

Juvenile rainbow trout ( $\sim 10 \mathrm{~cm}$ in length) were tested for survival in continuously-flowing solutions of $\mathrm{Li}^{+}$. Statistical interpretations of egg and fry bioassay results suggested that $\mathrm{Li}_{2} \mathrm{CO}_{3}$ was consistently more toxic than $\mathrm{LiF}$ to developmental stages of trout (Table A4). Thus, we tested acute responses of juveniles to only $\mathrm{Li}_{2} \mathrm{CO}_{3}$ to allow for more tests of a single compound and greater numbers of test concentrations. Single-pass deliveries of specific $\mathrm{Li}_{2} \mathrm{CO}_{3}$ concentrations were maintained by proportional diluters based on the design of Mount and Brungs (1967).

In the three final tests, five $\mathrm{Li}^{+}$concentrations plus control were delivered to replicated exposure aquaria at a rate of $0.1 \mathrm{~L} / \mathrm{min}( \pm 0.01 \mathrm{~L} / \mathrm{min})$. Each exposure-aquarium replicate had a volume of $30 \mathrm{~L}$, producing a hydraulic retention time of five hours. Experimental concentrations of $\mathrm{Li}^{+}$and controls were replicated twice, and each replicate held 10 or 25 juvenile trout.

Experimental fish were exposed to test solutions of $\mathrm{Li}^{+}$for 30 days in Tests 1 and 2, and 10 days in Test 3. Survival ratios are reported for exposure durations of 10 and 30 days. Intended exposure concentrations of $\mathrm{Li}^{+}$are shown in Tables $\mathrm{A} 5$ to $\mathrm{A} 7$. In Test 1 , the highest intended concentration of $\mathrm{Li}^{+}$ $(1.0 \mathrm{mg} / \mathrm{L})$ was monitored twice week $1 \mathrm{y}$. Lower test concentrations were proportionally diluted from this $1.0 \mathrm{mg} / \mathrm{L}$ stock solution. More-intensive monitoring of Tests 2 and 3 involved analyzing each experimental concentration of $\mathrm{Li}^{+}$once or twice weekly. Experimental Li concentrations were analyzed by the same methods described in Appendix 1.1.1.

Temperatures in the exposure aquarium were maintained with a $10^{\circ} \mathrm{C}$ water bath and monitored continuously using a YSI temperature recorder. Observations of $\mathrm{pH}$, dissolved oxygen, total alkalinity and total hardness were made twice weekly using methods described in Appendix 1.1.1. 
TABLE A4. Statistical answers to two questions regarding the toxicity of $\mathrm{LiF}_{\text {and }} \mathrm{Li}_{2} \mathrm{CO}_{3}$ : 1) Are the treatment results of either compound different from controls?, and 2) Does either compound exhibit greater toxicity in any test?

\begin{tabular}{|c|c|c|c|c|c|}
\hline \multirow[b]{3}{*}{ PARAMETER } & \multirow[b]{3}{*}{$\begin{array}{c}\text { TEST } \\
\text { NUMBER } \\
\end{array}$} & \multicolumn{4}{|c|}{$\begin{array}{l}\text { STATISTICAL HYPOTHESIS } \\
\text { (FOR DETECTING SIGNIFICANT DIFFERENCE, S, AT } \alpha=0.05 \text { ) }\end{array}$} \\
\hline & & \multicolumn{2}{|c|}{ CONTROL = TREAT. AVE. } & \multicolumn{2}{|c|}{ LiF TREAT. $=\mathrm{Li}_{2} \mathrm{CO}_{3}$ TREAT. } \\
\hline & & LiF TREAT. & $\mathrm{Li}_{2} \mathrm{CO}_{3}$ TREAT. & $\mathrm{LiF}=\mathrm{Li}_{2} \mathrm{CO}_{3}$ & $\begin{array}{l}\text { MORE-TOXIC } \\
\text { COMPOUND (a) }\end{array}$ \\
\hline RAINBOW TROUT: & & & & & \\
\hline - EGG INTEGRITY & $\begin{array}{l}1 \\
2 \\
3\end{array}$ & $\begin{array}{l}S \\
S \\
S\end{array}$ & $\begin{array}{l}S \\
S \\
S\end{array}$ & $\begin{array}{l}\text { NOT S } \\
\text { S } \\
\text { NOT S }\end{array}$ & $\mathrm{Li}_{2} \mathrm{CO}_{3}$ \\
\hline - EGG FERTILIZATION & $\begin{array}{l}1 \\
2 \\
3\end{array}$ & $\begin{array}{l}\text { NOT S } \\
\text { NOT S } \\
\text { NOT S }\end{array}$ & $\begin{array}{r}S \\
\text { NOT } \\
S\end{array}$ & $\begin{array}{r}S \\
\text { NOT } S \\
S\end{array}$ & $\begin{array}{l}\mathrm{Li}_{2} \mathrm{CO}_{3} \\
\mathrm{Li}_{2} \mathrm{CO}_{3}\end{array}$ \\
\hline - EMBRYOGENESIS & $\begin{array}{l}1 \\
2 \\
3\end{array}$ & $\begin{array}{l}S \\
S \\
S\end{array}$ & $\begin{array}{l}S \\
S \\
S\end{array}$ & $\begin{array}{l}S \\
S \\
S\end{array}$ & $\begin{array}{l}\mathrm{Li}_{2} \mathrm{CO}_{3} \\
\mathrm{Li}_{2} \mathrm{CO}_{3}\end{array}$ \\
\hline - HATCHABILITY & $\begin{array}{l}1 \\
2 \\
3\end{array}$ & $\begin{array}{l}S \\
S \\
S\end{array}$ & $\begin{array}{l}S \\
S \\
S\end{array}$ & $\begin{array}{l}S \\
S \\
S\end{array}$ & $\begin{array}{l}\mathrm{Li}_{2} \mathrm{CO}_{3} \\
\mathrm{Li}_{2} \mathrm{CO}_{3} \\
\mathrm{Li}_{2} \mathrm{CO}_{3}\end{array}$ \\
\hline - SAC-FRY SURVIVAL & $\begin{array}{l}1 \\
2 \\
3\end{array}$ & $\begin{array}{l}S \\
S \\
S\end{array}$ & $\begin{array}{l}S \\
S \\
S\end{array}$ & $\begin{array}{r}S \\
S \\
\text { NOT S }\end{array}$ & $\begin{array}{l}\mathrm{Li}_{2} \mathrm{CO}_{3} \\
\mathrm{Li}_{2} \mathrm{CO}_{3} \\
\mathrm{Li}_{2} \mathrm{CO}_{3}\end{array}$ \\
\hline $\begin{array}{l}\text { COLUMBIA RIVER PERIPHYTON: } \\
\text { - BIOMASS }\end{array}$ & $\begin{array}{l}\text { PRE-1 } \\
\text { PRE-2 } \\
\text { PRE-3 }\end{array}$ & $\begin{array}{l}S \\
S \\
S\end{array}$ & $\begin{array}{l}S \\
S \\
S\end{array}$ & $\begin{array}{l}s^{(c)} \\
\text { NOT } S \\
\text { NOT } S\end{array}$ & LiF \\
\hline
\end{tabular}

(a) THE LITHIUM COMPOUND (LIF OR LI2CO3) SHOWING GREATER TOXICITY

(b) PRELIMINARY TEST RUNS (15 DAYS) CONDUCTED PRIOR TO FIRST TEST RUN (MAY 30, 1979)

(c) SIGNIFICANT ONLY AT Li ${ }^{+}$CONCENTRATIONS $>78 \mathrm{mg} / \mathrm{L}$ 
TABLE A5. Experimental conditions and results of the first test where juvenile trout were exposed to elevated $\mathrm{Li}^{+}$concentrations. Results producing LRCTs are enclosed in boxes.

TEST 1:

\section{PARAMETERS}

INTENDED Li ${ }^{+}$EXPOSURE CONC. (mg/L) MEASURED Li ${ }^{+}$CONC. (mg/L) - MEAN

$$
\text { - } \pm \text { c.i. (a) }
$$$$
\text { - }(\mathrm{n})(\mathrm{c})
$$

TEST DURATION (DAYS / DATES)
DISSOLVED OXYGEN (RANGE, $\mathrm{mg} / \mathrm{L}$ )

pH (RANGE)

TOTAL ALKALINITY (RANGE, mg/L AS Ca CO $\mathrm{CO}_{3}$ )

TOTAL HARDNESS (RANGE, $\mathrm{mg} / \mathrm{L} \mathrm{AS} \mathrm{CaCO}_{3}$ )

SURVIVAL RATIO @ 10 DAYS $\left(\frac{\text { FISH SURVIVING }}{\text { TOTALFISH }}\right)$

SURVIVAL RATIO @ 30 DAYS $\left(\frac{\text { FISH SURVIVING }}{\text { TOTALFISH }}\right)$

\section{EXPERIMENTAL CONDITIONS}

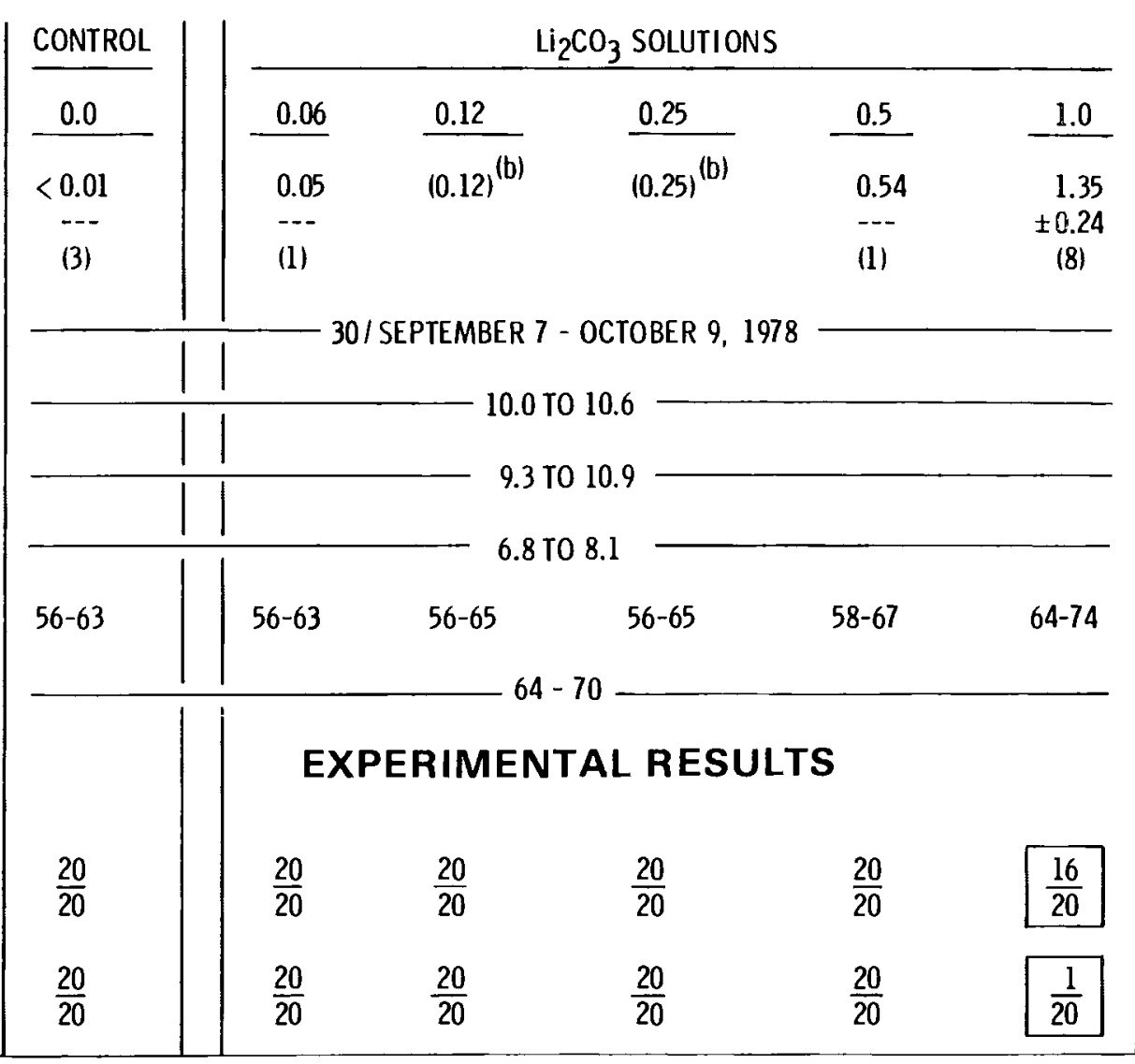

(a) STATISTICAL CONFI DENCE INTERVAL ABOUT THE MEAN AT $\alpha=0.05$

(b) ASSUMED CONCENTRATION, NO $\mathrm{Li}^{+}$ANALYSES PERFORMED

(c) NUMBER OF OBSERVATIONS 
TABLE A6. Experimental conditions and results of the second test where juvenile trout were exposed to elevated $\mathrm{Li}^{+}$concentrations. Results producing LRCTs are enclosed in boxes.

\section{TEST 2:}

\begin{tabular}{|c|c|}
\hline \multicolumn{2}{|l|}{ PARAMETERS } \\
\hline INTENDED Li ${ }^{+}$EXPOSURE CONC & $(\mathrm{mg} / \mathrm{L})$ \\
\hline MEASURED Li ${ }^{+}$CONC. $(\mathrm{mg} / \mathrm{L})$ & $\begin{array}{l}- \text { MEAN } \\
- \pm c . i{ }^{(a)} \\
-(n)^{(b)}\end{array}$ \\
\hline
\end{tabular}

TEST DURATION (DAYS / DATES)

TEMPERATURE (RANGE, ${ }^{\circ} \mathrm{C}$ )

DISSOLVED OXYGEN (RANGE, mg/L)

PH (RANGE)

TOTAL ALKALINITY (RANGE, mg/L AS $\mathrm{CaCO}_{3}$ )

TOTAL HARDNESS (RANGE, mg/L AS $\mathrm{CaCO}_{3}$ )

SURVIVAL RATIO @ 10 DAYS $\left(\frac{\text { FISH SURVIVING }}{\text { TOTAL FISH }}\right)$

SURVIVAL RATIO @ 30 DAYS ( $\frac{\text { FISH SURVIVING }}{\text { TOTALFISH }}$ )
EXPERIMENTAL CONDITIONS

\begin{tabular}{|c|c|c|c|c|c|}
\hline CONTROL & \multicolumn{5}{|c|}{$\mathrm{Li}_{2} \mathrm{CO}_{3}$ SOLUTIONS } \\
\hline 0.0 & 0.25 & 0.5 & 1.0 & 2.0 & 4.0 \\
\hline $\begin{array}{c}<0.01 \\
-(3)\end{array}$ & $\begin{array}{c}0.23 \\
\pm 0.10 \\
\text { (3) }\end{array}$ & $\begin{array}{r}0.49 \\
\pm 0.09 \\
\text { (3) }\end{array}$ & $\begin{array}{r}1.03 \\
\pm 0.22 \\
\text { (3) }\end{array}$ & $\begin{array}{r}1.98 \\
\pm 0.88 \\
\text { (2) }\end{array}$ & $\begin{array}{c}3.80 \\
\pm 1.23 \\
(2)\end{array}$ \\
\hline & 300 & ST $14-$ & IBER & & \\
\hline & & 9.4 & & & - \\
\hline $56-63$ & $57-65$ & $59-67$ & $62-72$ & $77-84$ & $75-99$ \\
\hline & & ERIM & AL R & & \\
\hline$\frac{50}{50}$ & $\frac{50}{50}$ & $\frac{49}{50}$ & $\frac{13}{50}$ & $\frac{0}{50}$ & $\frac{0}{50}$ \\
\hline$\frac{50}{50}$ & $\frac{50}{50}$ & $\frac{48}{50}$ & $\frac{0}{50}$ & $\frac{0}{50}$ & $\frac{0}{50}$ \\
\hline
\end{tabular}

(a) STATISTICAL CONFI DENCE INTERVAL ABOUT THE MEAN AT $a=0.05$

(b) NUMBER OF OBSERVATIONS 
TABLE A7. Experimental conditions and results of the third test where juvenile trout were exposed to elevated $\mathrm{Li}^{+}$concentrations. Results producing LRCTs are enclosed in boxes.

\section{TEST 3:}

PARAMETERS

INTENDED Li ${ }^{+}$EXPOSURE CONC. (mg/L)

MEASURED Li ${ }^{+}$CONC. $(\mathrm{mg} / \mathrm{L})$ - MEAN

- \pm c.i. (a)

- $(n)(b)$

TEST DURATION (DAYS/DATES)

TEMPERATURE (RANGE, ${ }^{\circ} \mathrm{C}$ )

$\stackrel{?}{\sim}$

DISSOLVED OXYGEN (RANGE, $\mathrm{mg} / \mathrm{L}$ )

PH (RANGE)

TOTAL ALKALINITY (RANGE, mg/L AS $\mathrm{CaCO}_{3}$ )

TOTAL HARDNESS (RANGE, mg/L AS $\mathrm{CaCO}_{3}$ )

LARGE FISH ${ }^{(\mathrm{C})}$ SURVIVAL RATIO $\left(\frac{\text { FISH SURVIVING }}{\text { TOTAL FISH }}\right)$

SMALL FISH ${ }^{\text {(d) }}$ SURVIVAL RATIO $\left(\frac{\text { FISH SURVIVING }}{\text { TOTALFISH }}\right)$

\section{EXPERIMENTAL CONDITIONS}

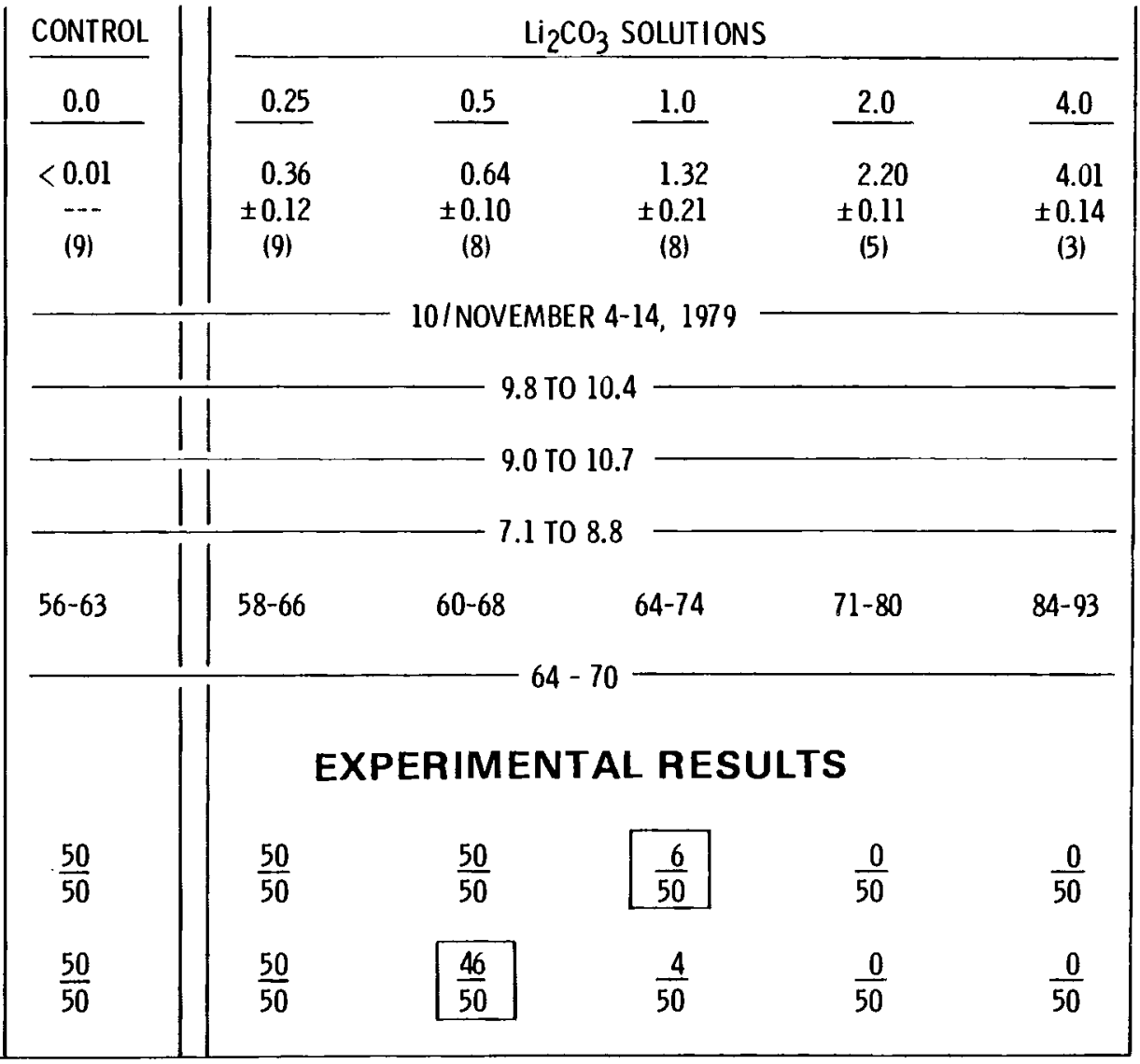

(a) STATISTICAL CONFIDENCE INTERVAL ABOUT THE MEAN AT $\alpha=0.05$

(b) NUMBER OF OBSERVATIONS

(c) $13.28 \mathrm{~g} \pm 1.53 \mathrm{~g}$ (MEAN WET WEIGHT \pm c.i. AT $a=0.05$ ), LENGTH $=11 \mathrm{~cm}$

(d) $8.45 \mathrm{~g} \pm 1.08 \mathrm{~g}$ (MEAN WET WEIGHT $\pm \mathrm{c} . \mathrm{i}$. AT $a=0.05$ ), LENGTH $=9 \mathrm{~cm}$ 


\subsection{EXPERIMENTS WITH COLUMBIA RIVER BIOTA}

\subsection{THE EXPERIMENTAL SYSTEM}

Columbia River periphyton and midge larvae (Chironomus sp.) were exposed to continuous solutions of $\mathrm{Li}^{+}$to relate their responses to specific concentrations. These experiments focused on the ability of test organisms to sustain their populations in the elevated $\mathrm{Li}^{+}$concentrations of our exposure containers. Tests were performed under direct sunlight and at ambient temperatures of Columbia River water. Each exposure container received a continuous supply (single-pass) of raw river water which served two purposes. Raw river water both supplied the "seed" for experimental periphyton populations and diluted the $\mathrm{Li}^{+}$stock solution to appropriate test concentrations.

Continuous deliveries of specific $\mathrm{Li}^{+}$concentrations were supplied by the serial-dilution system shown in Figure $A 2$. All hardware components are made of glass, lucite and flexible plastic tubing. The $\mathrm{Li}^{+}$stock concentrate was serially diluted with river water to desired concentrations, and delivered to exposure containers at a rate of $0.1 \mathrm{~L} / \mathrm{min}( \pm 0.01 \mathrm{~L} / \mathrm{min})$. Internal flow adjustments necessary to calibrate the diluter were made daily throughout each test by changing positions of the delivery arms (Figure A3).

Exposure containers were made of plastic and had 2-L capacities (Figure A3). Their hydraulic retention time ( $/ Q$ ) was $20 \mathrm{~min}$. Ambient river temperatures were maintained in exposure containers with a river-water bath. Experimental temperatures were monitored with a YSI probe and recorder. Observations of $\mathrm{pH}$, total alkalinity and total hardness were made twice weekly during experiments using techniques described in Appendix 1.1.1.

Preliminary scoping tests were performed using both $\mathrm{LiF}$ and $\mathrm{Li}_{2} \mathrm{CO}_{3}$ solutions. Statistical interpretations of these results (Table A4) showed that both compounds were similarly toxic, except LiF was more toxic at concentrations $>78 \mathrm{mg} / \mathrm{L}$. Since $\mathrm{Li}_{2} \mathrm{CO}_{3}$ was frequently more toxic than $\mathrm{LiF}$ to developing trout, we elected to use only $\mathrm{Li}_{2} \mathrm{CO}_{3}$ in the final tests. This allowed us to expand the number of test concentrations and their replication. 
DIAGRAM OF SERIAL DILUTION DELIVERY SYSTEM

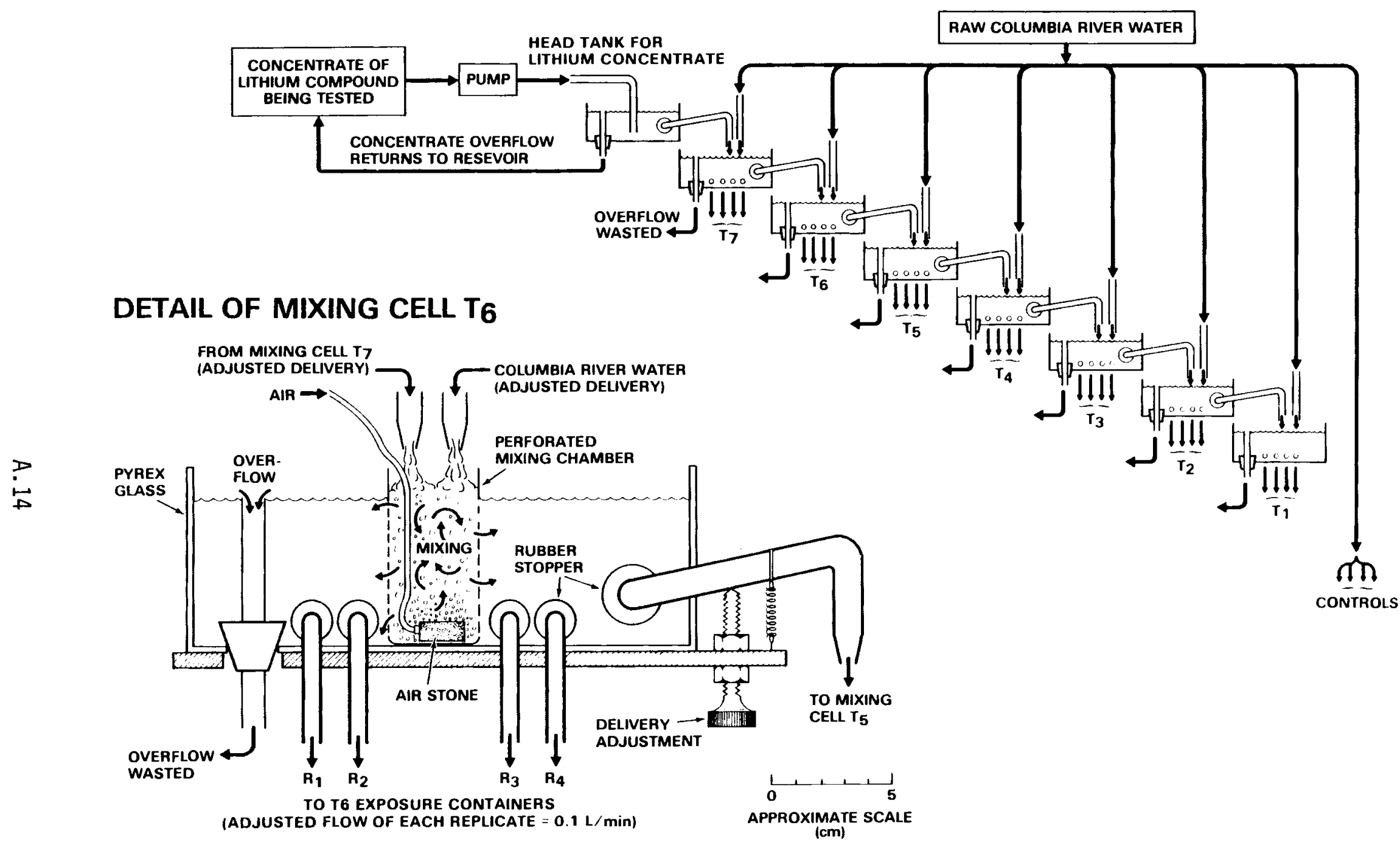

FIGURE A2. The serial dilution system used to deliver elevated $\mathrm{Li}^{+}$concentrations to Columbia River biota. 


\section{TOP VIEW OF EXPOSURE CONTAINERS IN WATER BATH}

RAW COLUMBIA RIVER WATEA (FLOW RATE $=20 \mathrm{~L} / \mathrm{min}$.)

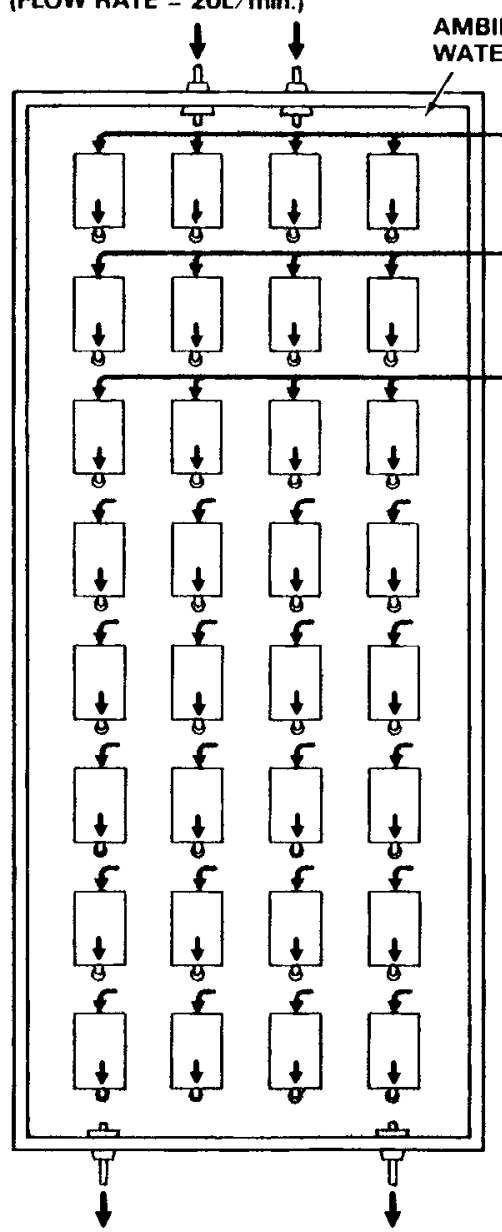

- CONTAINERS RANDOMLY DISTRIBUTED

EXITS FOR WATER BATH

- WATER FLOW THROUGH CONTAINERS RUNS

NORTH-SOUTH

MBIENT TEMPERATURE TER TATH

SERIAL DILUTION

SYSTEM PROVIOES

32 INDEPENDENT

(SEE FIG. A2)

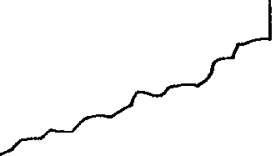

DETAIL OF EXPOSURE CONTAINER

- CONTAINER VOLUME $=2 \mathrm{~L}$

- INFLOW RATE $=0.1 \mathrm{~L} / \mathrm{min}$.

- RETENTION TIME = $20 \mathrm{~min}$

DELIVERY FROM

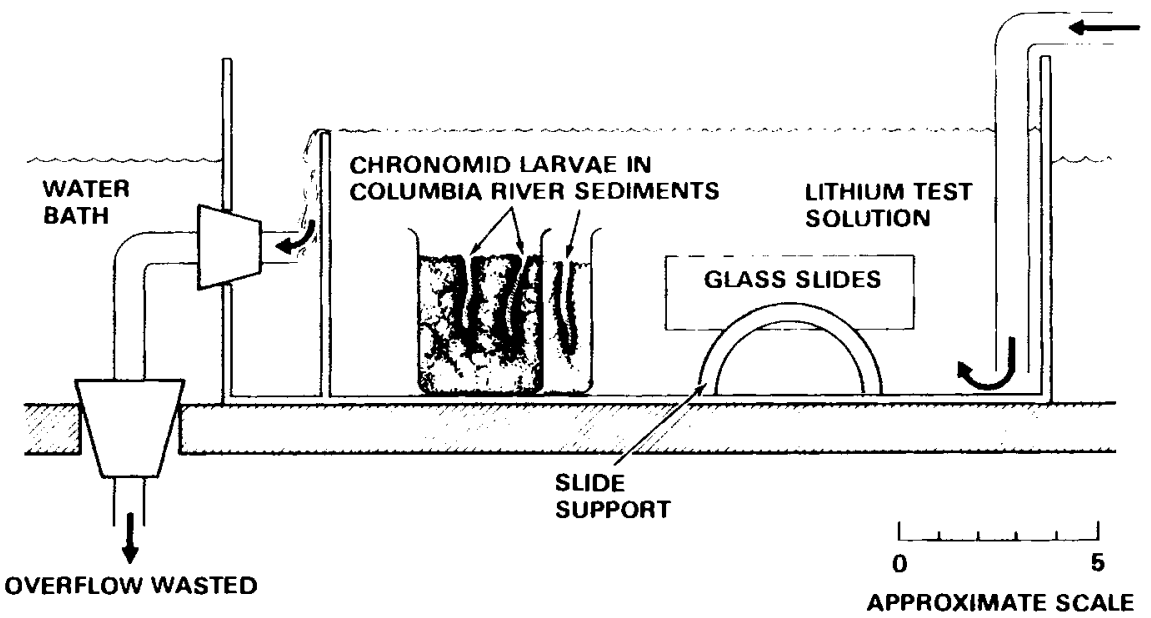

$(\mathrm{cm})$

FIGURE A3. Experimental array and detail of exposure containers used to test Columbia River biota in elevated $\mathrm{Li}^{+}$concentrations. 
In our four final tests, we exposed Columbia River organisms to seven $\mathrm{Li}^{+}$ concentrations plus control for 15 days (Tables A8 to A11). Test populations of periphyton colonized naturally in our exposure containers during experimental periods. Chironomid larvae were collected from McNary reservoir and acclimated in laboratory aquaria containing McNary sediments for 10 days. Larvae-exposure modules (Figure A3) were prepared and again acclimated in laboratory aquaria for 3 days prior to each test run.

The seven test concentrations and control were allocated to the water table (Figure A3) in a randomized block design where the treatment levels were randomly assigned to the eight exposure containers within each pair of consecutive rows. The test concentrations and controls were replicated four times.

Analysis of variance for a two-way classification was used to analyze biomass data (Tables A8-A11). Subsequent analyses using Fisher's protected LSD (least significant difference) test was employed to determine the LRCT values. Because of unequal treatment variances, Friedman rank sum test for a two-way layout was used to analyze the photosynthetic-rate data (Tables A8-A11). No significant block effects were found. Wilcoxon rank sum tests were then used to compare survival rates of treatment versus control groups of larvae (Tables A8-A11) for insect habitation.

\subsection{MEASUREMENTS OF BIOLOGICAL PARAMETERS}

Three biological parameters were measured that define a quantitative association between $\mathrm{Li}^{+}$concentrations and the inhabitability of our exposure containers. To account for the habitation of periphyton, we measured the total biomass and photosynthetic rate of algae growing in the exposure containers on the fifteenth day. To measure the habitation of insect larvae, we counted numbers of chironomids remaining in the exposure modules after 14 days.

Measurements of net photosynthetic rates were made from dawn to noon on the last day of testing. Water flow was stopped during these periods of measurement. We used Verduin's technique (1964) that related pH changes in exposure containers with changes in $\mathrm{CO}_{2}$ concentrations. For each experimental 
TABLE A8. Experimental conditions and results of the first test where periphyton and insect larvae were exposed to elevated $\mathrm{Li}^{+}$concentrations. Results producing LRCTs are enclosed in boxes.

\section{TEST 1:}

\section{EXPERIMENTAL CONDITIONS}

\section{PARAMETERS}

INTENDED Li ${ }^{+}$EXPOSURE CONC. (mg/L)

MEASURED Li ${ }^{+}$CONC. (mg/L) • MEAN

- \pm c.i. (a)

- $(n)(b)$

TEST DURATION (DAYS / DATES)

TEMPERATURE (RANGE, ${ }^{\circ} \mathrm{C}$ )

PH (RANGE)

i TOTAL ALKALINITY (RANGE, $\mathrm{mg} / \mathrm{L} \mathrm{AS} \mathrm{CaCO}_{3}$ )

TOTAL HARDNESS (RANGE, mg/L AS $\mathrm{CaCO}_{3}$ )

BIOMASS (mg, ASH-FREE DRY WT)

- MEAN

- (n)

PHOTOSYNTHETIC RATE $(\mathrm{mg} \mathrm{C} / \mathrm{L} \cdot \mathrm{DAY}) \cdot$ MEAN

- \pm c.i. (c)

- (n)

INSECT HABITATION

$$
\text { ( } \left.\frac{\text { LARVAE REMAINING }}{\text { TOTAL LARVAE EXPOSED }}\right)
$$

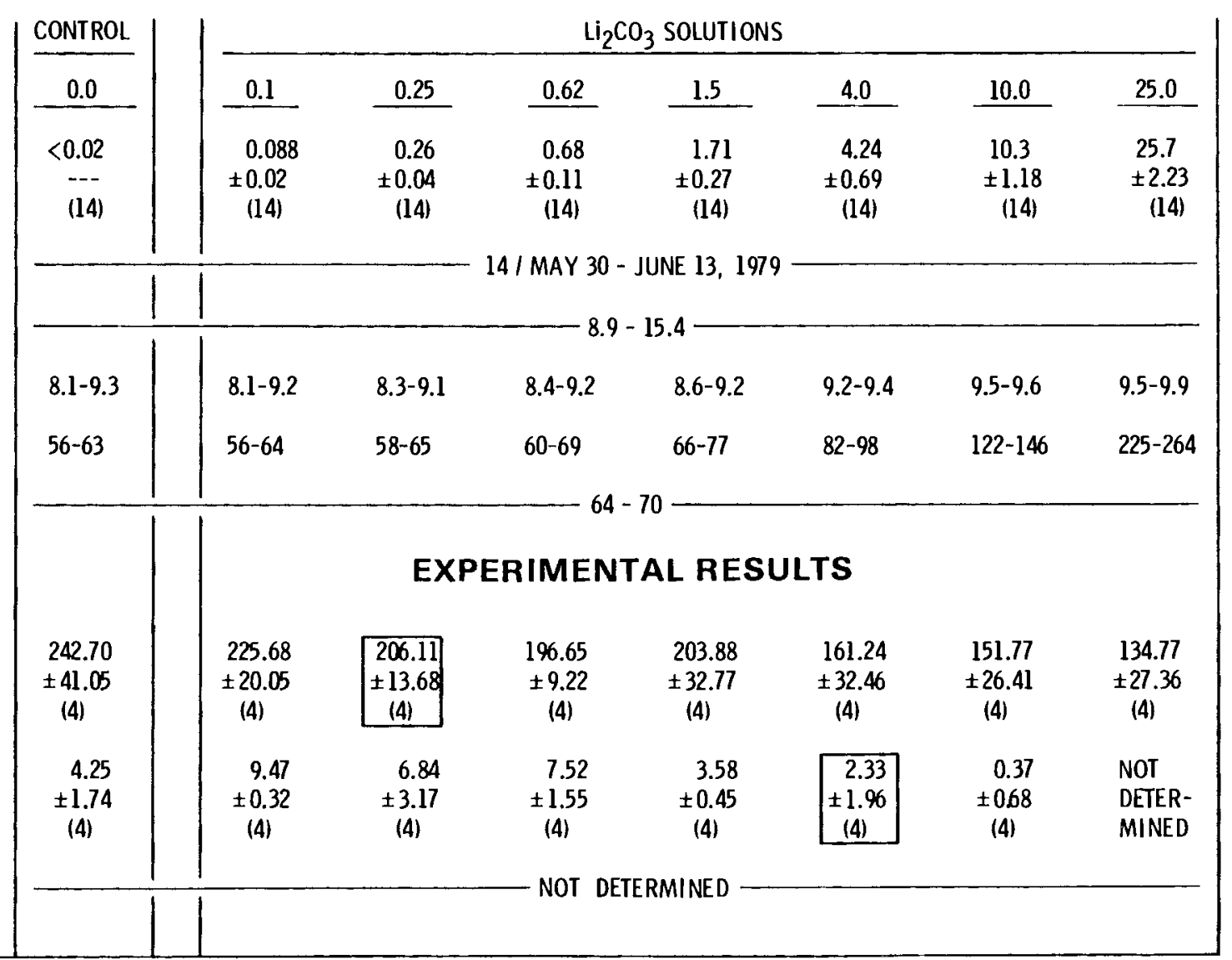

(a) STATISTICAL CONFI DENCE INTERVAL ABOUT THE MEAN AT $a=0.05$

(b) NUMBER OF OBSERVATIONS

(c) SPECIFIC c.i. 'S MAY NOT REFLECT THE RESULTS OF ANOVA PROCEDURES FOR LRCT DETERMINATIONS, WHICH USED POOLED VARIANCE ESTIMATES 
TABLE A9. Experimental conditions and results of the second test where periphyton and insect larvae were exposed to elevated $\mathrm{Li}^{+}$concentrations. Results producing LRCTs are enclosed in boxes.

TEST 2:

PARAMETERS

INTENDED Li EXPOSURE CONC. Img/L)

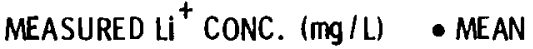
- \pm ci. (a)

TEST DURATION (DAYS IDATES)

TEMPERATURE (RANGE, ${ }^{0} \mathrm{C}$ )

TOTAL ALKALINITY (RANGE, mg/L AS Ca CO

TOTAL HARDNESS (RANGE, mg/L AS $\mathrm{CaCO}_{3}$ )

BIOMASS (mg, ASH-FREE DRYWT) $\bullet$ MEAN $\bullet \pm$ (n)

PHOTOSYNTHETIC RATE (mg C /L - DAY) - MEAN

$$
\text { - } \pm \text { c.i. }{ }^{\text {(C) }}
$$$$
\text { - (n) }
$$

INSECT HABITATION $\left(\frac{\text { LARVAE REMAINING }}{\text { TOTAL LARVAE EXPOSED }}\right)$
PH (SINGLE OBSERVATION ON DAY-14)

EXPERIMENTAL CONDITIONS

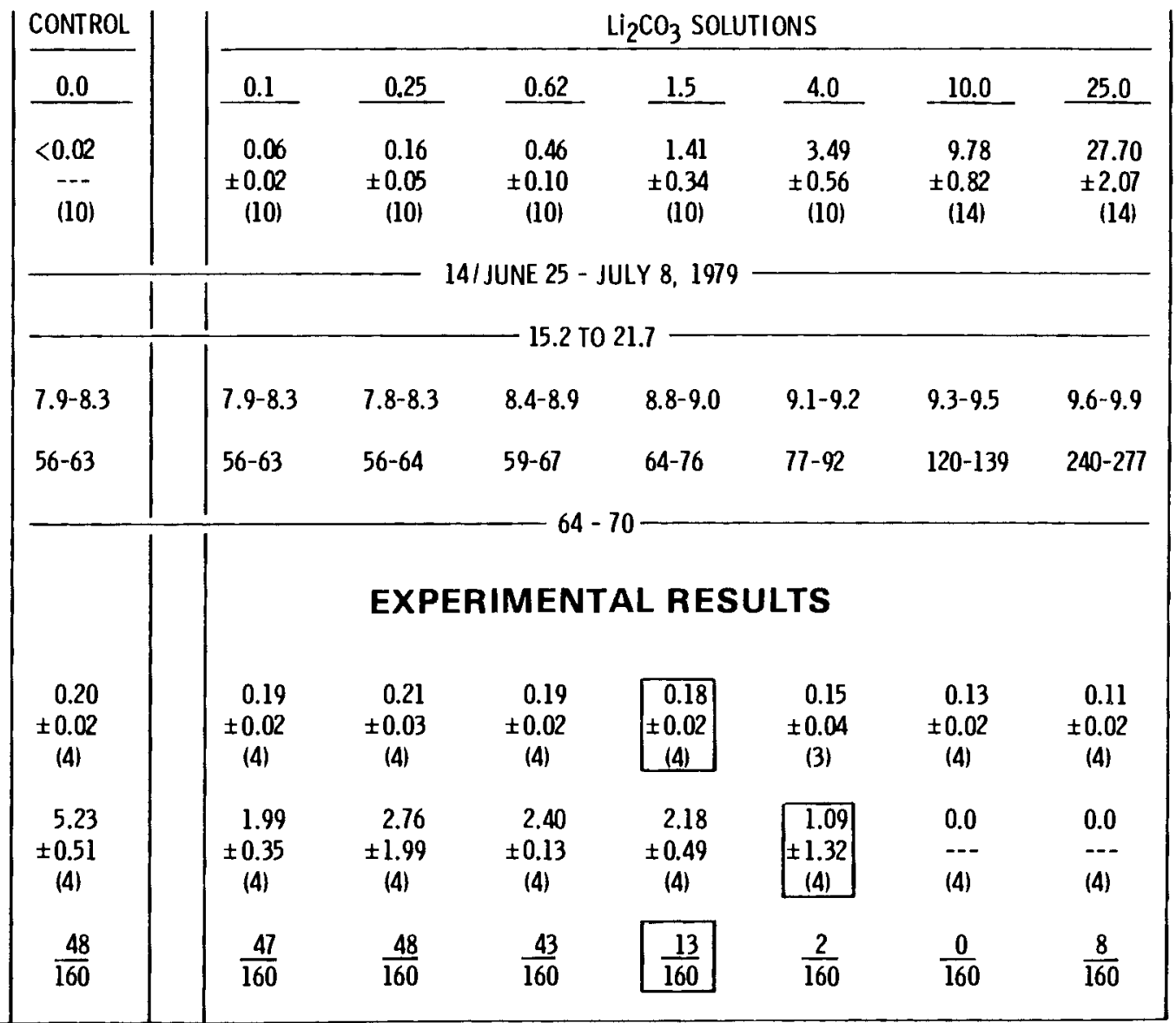

(a) STATISTICAL CONFIDENCE INTERVAL ABOUT THE MEAN AT $a=0.05$

(b) NUMBER OF OBSERVATIONS

(c) SPECIFIC C.i. 'S MAY NOT REFLECT THE RESULTS OF ANOVA PROCEDURES FOR LRCT DETERMINATIONS, WHICH USED POOLED VARIANCE ESTIMATES 
TABLE A10. Experimental conditions and results of the third test where periphyton and insect larvae were exposed to elevated $\mathrm{Li}^{+}$concentrations. Results producing LRCTs are enclosed in boxes.

TEST 3:

$\frac{\text { PARAMETERS }}{\text { INTENOED Li }{ }^{+} \text {EXPOSURE CONC. (mg/L) }}$
$\begin{aligned} \text { MEASURED Li }{ }^{+} \text {CONC. (mg/L) } & \text { MEAN (a) } \\ & \pm \text { c.i. }{ }^{\text {(b) }}\end{aligned}$

TEST DURATION (DAYS/ DATES)

TEMPERATURE (RANGE, ${ }^{\circ} \mathrm{C}$ )

它

pH

TOTAL ALKALINITY (RANGE, $\mathrm{mg} / \mathrm{L} \mathrm{AS} \mathrm{CaCO}_{3}$ )

TOTAL HARDNESS (RANGE, $\mathrm{mg} / \mathrm{LAS} \mathrm{CaCO}_{3}$ )

BIOMASS (mg, ASH-FREE DRY WT) - MEAN

- $\dot{\text { i c.i. }}$. (c)

- (n)

PHOTOS YNTHETIC RATE $(\mathrm{mg} \mathrm{C} / \mathrm{L} \cdot \mathrm{DAY}) \cdot \mathrm{MEAN}$

- t c. i (c)

- (n)

INSECT HABITATION ( LARVAE REMAINING

\section{EXPERIMENTAL CONDITIONS}

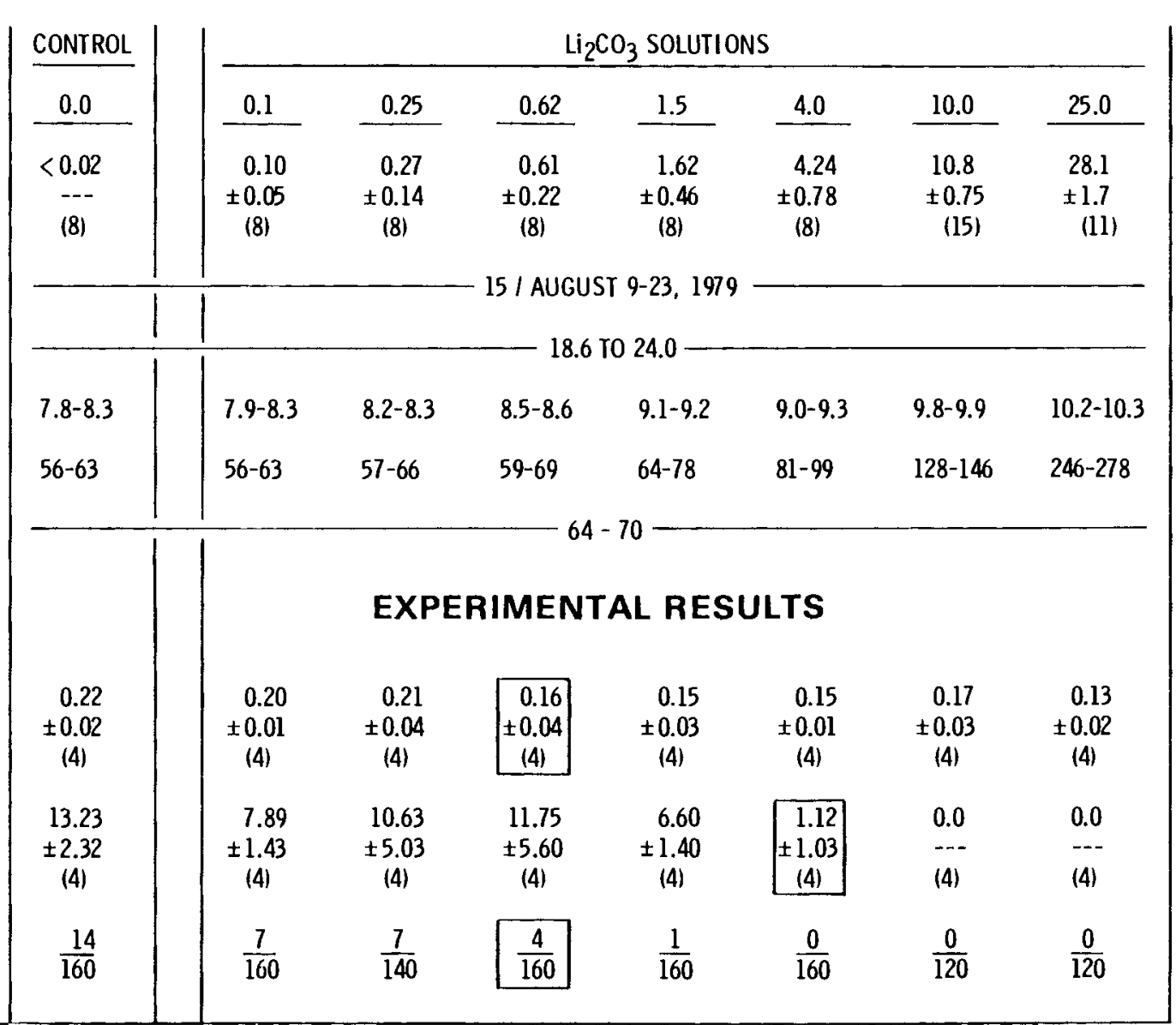

\section{EXPERIMENTAL RESULTS}

\begin{tabular}{|c|c|c|c|c|c|c|c|}
\hline CONTROL & \multicolumn{7}{|c|}{$\mathrm{Li}_{2} \mathrm{CO}_{3}$ SOLUTIONS } \\
\hline 0.0 & 0.1 & 0.25 & 0.62 & 1.5 & 4.0 & 10.0 & 25.0 \\
\hline $\begin{array}{c}<0.02 \\
--- \\
(8)\end{array}$ & $\begin{array}{c}0.10 \\
\pm 0.05 \\
(8)\end{array}$ & $\begin{array}{c}0.27 \\
\pm 0.14 \\
(8)\end{array}$ & $\begin{array}{c}0.61 \\
\pm 0.22 \\
(8)\end{array}$ & $\begin{array}{c}1.62 \\
\pm 0.46 \\
(8)\end{array}$ & $\begin{array}{r}4.24 \\
\pm 0.78 \\
(8)\end{array}$ & $\begin{array}{r}10.8 \\
\pm 0.75 \\
(15)\end{array}$ & $\begin{array}{r}28.1 \\
\pm 1.7 \\
(11)\end{array}$ \\
\hline $7.8-8.3$ & $7.9-8.3$ & $8.2-8.3$ & $8.5-8.6$ & $9.1-9.2$ & $9.0-9.3$ & $9.8-9.9$ & $10.2-10.3$ \\
\hline $56-63$ & $56-63$ & $57-66$ & $59-69$ & $64-78$ & $81-99$ & $128-146$ & $246-278$ \\
\hline & & EXP & IMEN & L RE & LTS & & \\
\hline $\begin{array}{c}0.22 \\
\pm 0.02 \\
(4)\end{array}$ & $\begin{array}{r}0.20 \\
\pm 0.01 \\
(4)\end{array}$ & $\begin{array}{r}0.21 \\
\pm 0.04 \\
(4)\end{array}$ & \begin{tabular}{|c|}
0.16 \\
\pm 0.04 \\
$(4)$ \\
\end{tabular} & $\begin{array}{r}0.15 \\
\pm 0.03 \\
\text { (4) }\end{array}$ & $\begin{array}{r}0.15 \\
\pm 0.01 \\
(4)\end{array}$ & $\begin{array}{r}0.17 \\
\pm 0.03 \\
(4)\end{array}$ & $\begin{array}{r}0.13 \\
\pm 0.02 \\
(4)\end{array}$ \\
\hline $\begin{array}{c}13.23 \\
\pm 2.32 \\
(4)\end{array}$ & $\begin{array}{r}7.89 \\
\pm 1.43 \\
(4)\end{array}$ & $\begin{array}{c}10.63 \\
\pm 5.03 \\
\text { (4) }\end{array}$ & $\begin{array}{c}11.75 \\
\pm 5.60 \\
(4)\end{array}$ & $\begin{array}{r}6.60 \\
\pm 1.40 \\
\text { (4) }\end{array}$ & $\begin{array}{r}1.12 \\
\pm 1.03 \\
(4)\end{array}$ & $\begin{array}{l}0.0 \\
-- \\
(4)\end{array}$ & $\begin{array}{l}0.0 \\
--- \\
(4)\end{array}$ \\
\hline$\frac{14}{160}$ & $\frac{7}{160}$ & $\frac{7}{140}$ & $\frac{4}{160}$ & $\frac{1}{160}$ & $\frac{0}{160}$ & $\frac{0}{120}$ & $\frac{0}{120}$ \\
\hline
\end{tabular}

(a) STATISTICAL CONFI DENCE INTERVAL ABOUT THE MEAN AT $a=0.05$

(b) NUMBER OF OBSERVATIONS

(c) SPECIFIC C.i. 'S MAY NOT REFLECT THE RESULTS OF ANOVA PROCEDURES FOR LRCT DETERMINATIONS, WHICH USED POOLED VARIANCE ESTIMATES 
TABLE A11. Experimental conditions and results of the fourth test where periphyton and insect larvae were exposed to elevated $\mathrm{Li}^{+}$concentrations. Results producing LRCTs are enclosed in boxes.

\section{TEST 4:}

EXPERIMENTAL CONDITIONS

\begin{tabular}{|c|c|c|c|c|c|c|c|c|}
\hline \multirow{2}{*}{ 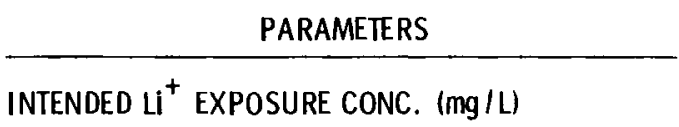 } & \multirow{2}{*}{$\frac{\text { CONTROL }}{0.0}$} & \multicolumn{7}{|c|}{$\mathrm{Li}_{2} \mathrm{CO}_{3}$ SOLUTIONS } \\
\hline & & 0.1 & 0.25 & 0.62 & 1.5 & 4.0 & 10.0 & 25.0 \\
\hline $\begin{aligned} \text { MEASURED Li }{ }^{+} \text {CONC. }(m g / L) & \bullet \text { MEAN } \\
& : \pm c . i \text { (a) } \\
& \bullet(n)\end{aligned}$ & $\begin{array}{c}<0.02 \\
--- \\
(9)\end{array}$ & $\begin{array}{l}0.06 \\
\pm 0.03 \\
(9)\end{array}$ & $\begin{array}{r}0.17 \\
\pm 0.06 \\
(9)\end{array}$ & $\begin{array}{r}0.44 \\
\pm 0.12 \\
(9)\end{array}$ & $\begin{array}{l}1.21 \\
\pm 0.22 \\
(9)\end{array}$ & $\begin{array}{r}3.32 \\
\pm 0.36 \\
(9)\end{array}$ & $\begin{array}{r}9.38 \\
\pm 0.32 \\
(15)\end{array}$ & $\begin{array}{r}27.8 \\
\pm 1.24 \\
(15)\end{array}$ \\
\hline \multicolumn{9}{|l|}{ TEST DURATION (DAYS / DATES) } \\
\hline \multicolumn{9}{|l|}{ TEMPERATURE (RANGE, ${ }^{0} \mathrm{C}$ ) } \\
\hline pH (RANGE) & $7.5-8.3$ & $7.9-8.3$ & $7.8-8.3$ & $7.8-8.3$ & $8.1-8.3$ & $8.8-8.9$ & $9.2-9.3$ & $9.7-9.8$ \\
\hline TOTAL ALKALINITY (RANGE, mg/L AS $\mathrm{CaCO}_{3}$ ) & $56-63$ & $56-63$ & $57-65$ & $58-67$ & $63-73$ & $77-89$ & $121-133$ & $247-272$ \\
\hline \multicolumn{9}{|l|}{ TOTAL HARDNESS (RANGE, mg/L AS $\mathrm{CaCO}_{3}$ ) } \\
\hline & & \multicolumn{7}{|c|}{ EXPERIMENTAL RESULTS } \\
\hline $\begin{aligned} \text { BIOMASS (mg, ASH-FREE DRY WT) } & \bullet \text { MEAN } \\
& \bullet \pm c . i .(\mathrm{c}) \\
& \bullet(\mathrm{n})\end{aligned}$ & $\begin{array}{r}0.70 \\
\pm 0.45 \\
(4)\end{array}$ & $\begin{array}{r}0.54 \\
\pm 0.13 \\
(4)\end{array}$ & $\begin{array}{l}0.65 \\
\pm 0.05 \\
(4)\end{array}$ & \begin{tabular}{|c|}
0.43 \\
\pm 0.07 \\
$(4)$ \\
\end{tabular} & $\begin{array}{r}0.33 \\
\pm 0.06 \\
(4)\end{array}$ & $\begin{array}{r}0.38 \\
\pm 0.17 \\
(3)\end{array}$ & $\begin{array}{r}0.26 \\
\pm 0.07 \\
(4)\end{array}$ & $\begin{array}{r}0.13 \\
\pm 0.04 \\
(4)\end{array}$ \\
\hline $\begin{aligned} \text { PHOTOSYNTHETIC RATE }(m g \text { C/L } \cdot \text { DAY) } & : \text { MEAN } \\
& \bullet \pm c . i .(\mathrm{c}) \\
& \bullet(n)\end{aligned}$ & $\begin{array}{l}15.98 \\
\pm 5.66 \\
\text { (4) }\end{array}$ & $\begin{array}{l}19.1 \\
\pm 3.31 \\
(4)\end{array}$ & $\begin{array}{l}22.6 \\
\pm 2.59 \\
\text { (4) }\end{array}$ & $\begin{array}{l}24.0 \\
\pm 1.45 \\
(4)\end{array}$ & $\begin{array}{l}25.8 \\
\pm 1.80 \\
(4)\end{array}$ & $\begin{array}{l}30.1 \\
\pm 3.15 \\
(4)\end{array}$ & $\begin{array}{c}20.6 \\
\pm 0.99 \\
(3)\end{array}$ & $\begin{array}{r}8.2 \\
\pm 2.9 \\
(3) \\
\end{array}$ \\
\hline INSECT HABITATION $\left(\frac{\text { LARVAE REMAINING }}{\text { TOTAL LARVAE EXPOSED }}\right)$ & $\frac{19}{160}$ & $\frac{15}{160}$ & $\frac{11}{160}$ & $\frac{7}{160}$ & $\frac{3}{160}$ & $\frac{0}{160}$ & $\frac{0}{160}$ & $\frac{0}{160}$ \\
\hline
\end{tabular}

(a) STATI STICAL CONFIDENCE INTERVAL ABOUT THE MEAN AT $\alpha=0.05$

(b) NUMBER OF OBSERVATIONS

(c) SPECIFIC C.i. 'S MAY NOT REFLECT THE RESULTS OF ANOVA PROCEDURES FOR LRCT DETERMINATIONS, WHICH USED POOLED VARIANCE ESTIMATES 
concentration of $\mathrm{Li}_{2} \mathrm{CO}_{3}$, and the control, we determined changes in $\mathrm{pH}$ induced by the titration of $0.02 \mathrm{~N} \mathrm{NaOH}$ into $100 \mathrm{ml}$ of test water. Resulting changes of $\mathrm{CO}_{2}$ were calculated stoichiometrically from these data. This association was developed graphically to allow for the interpolation of $\mathrm{CO}_{2}$ consumption by the photosynthetic process. Thus, the difference of $\mathrm{pH}$ from dawn to noon infers the amount of photosynthesis expressed as $\mathrm{mg} \mathrm{C} / \mathrm{L}$.

Photosynthetic rates were calculated and expressed as $\mathrm{mg} C / \mathrm{L}$ per day. Rate calculations involved insolation data recorded daily at Battelle's meteorological station to establish a solar-day curve from dawn to dusk. This curve is a graphic relationship between time, in minutes of the solar day, and insolation in Langley's $\left(\mathrm{cal} / \mathrm{cm}^{2} / \mathrm{min}\right)$. From this we determined the total insolation $(\Sigma I)$ received on the day of the test, and the insolation received during the period of $\mathrm{pH}$ measurement $\left(I_{m}\right)$. Ratios of these quantities were then used to convert photosynthes is into a daily rate with the equation

$$
P_{r}=P \frac{\sum I}{I_{m}}
$$

where $P$ is a measure of photosynthes is in $m g C / L$ and $P_{r}$ is the net photosynthetic rate is $\mathrm{mg} \mathrm{C} / \mathrm{L} /$ day.

Periphyton biomass was measured by removing all of the algae from the water, walls and floors of exposure containers and drying the samples at $105^{\circ} \mathrm{C}$ in tarred crucibles.

After dry weights were determined on a Mettler Model $\mathrm{H64}$ microbalance, the samples were ash-fired at $500^{\circ} \mathrm{C}$ to permit complete combustion. The resulting ash weights were subtracted from dry weights to obtain a measurement of biomass (organic mass) expressed in $\mathrm{mg}$.

Standard glass microscope slides were also used as substrates for periphyton growth. These were placed in exposure containers (Fig. A3) to measure the diversity of diatom populations as a response to $\mathrm{Li}^{+}$concentrations. Although these samples have been collected on day 14, preserved, labeled and stored; diatom-diversity results will not be analyzed and discussed in this document. There are two reasons for this. 
First, the use of "species diversity" or taxonomic diversity as an indicator of organizational complexity and community structure has been the subject of much debate in the 1970's. The consenses on this matter among leading theoretical ecologists has caused the diversity notion to be largely abandoned (Emery 1981). Second, the time and expense of diatom sample preparation, taxonomic identification and interpretation of results fell beyond the resources of this research program.

The habitation of insects in our exposure containers was observed using the midge larvae from McNary Reservoir sediments. Test chironomids were held in experimental $\mathrm{Li}^{+}$concentrations within exposure modules (Figure A3). Each exposure module held 20 chironomids that were well-burrowed into $200 \mathrm{ml}$ of native sediments prior to testing. Two modules were placed in each replicate exposure container. Thus, each test concentration plus control exposed 160 larvae in the four replicates.

To measure habitation, we counted the number of larvae remaining after 14-day experimental periods. The ratio of larvae remaining to total numbers initially exposed formed a measure of habitation. This is only a relative measure, however, since it cannot be interpreted as direct evidence of toxic challenge. Chironomid larvae could have left because of metamorphic emergence of natural preference to downstream conditions. There were few dead larvae discovered in the experimental sediments. Nevertheless, the parameter proved to be sensitive to $\mathrm{Li}^{+}$and was also interpretable statistically. 
No. of

Copies

OFFSITE

A. A. Churm

DOE Patent Division

9800 S. Cass Avenue

Argonne, IL 60439

Helen McCammon, Director

Ecological Research Division, EV-34

Office of Health and

Environmental Research, GTN U.S. Department of Energy

Washington, D.C. 20545

R. L. Watters

Ecological Research Division, EV-34

Office of Health and

Environmental Research, GTN

U.S. Department of Energy

Washington, D.C. 20545

27 Technical Information Center
No. of

Copies

ONSITE
DOE Richland Operations Office

H. E. Ransom

Pacific Northwest Laboratory

C. D. Becker

C. E. Cushing

R. M. Emery (15)

K. E. Harding (4)

D. C. Klopfer (5)

T. L. Page

T. M. Poston

J. R. Skalski (5)

J. A. Strand

W. L. Templeton

B. E. Vaughan (20)

D. G. Watson Technical Information (5) Publishing Coordination (2) 


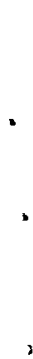

3

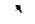

( 